\title{
Dysbiotic drift: mental health, environmental grey space, and microbiota
}

\author{
Alan C Logan
}

\begin{abstract}
Advances in research concerning the mental health implications of dietary patterns and select nutrients have been remarkable. At the same time, there have been rapid increases in the understanding of the ways in which non-pathogenic microbes can potentially influence many aspects of human health, including those in the mental realm. Discussions of nutrition and microbiota are often overlapping. A separate, yet equally connected, avenue of research is that related to natural (for example, green space) and built environments, and in particular, how they are connected to human cognition and behaviors. It is argued here that in Western industrial nations a 'disparity of microbiota' might be expected among the socioeconomically disadvantaged, those whom face more profound environmental forces. Many of the environmental forces pushing against the vulnerable are at the neighborhood level. Matching the developing microbiome research with existing environmental justice research suggests that grey space may promote dysbiosis by default. In addition, the influence of Westernized lifestyle patterns, and the marketing forces that drive unhealthy behaviors in deprived communities, might allow dysbiosis to be the norm rather than the exception in those already at high risk of depression, subthreshold (subsyndromal) conditions, and subpar mental health. If microbiota are indeed at the intersection of nutrition, environmental health, and lifestyle medicine (as these avenues pertain to mental health), then perhaps the rapidly evolving gut-brain-microbiota conversation needs to operate through a wider lens. In contrast to the more narrowly defined psychobiotic, the term eco-psychotropic is introduced.
\end{abstract}

\section{Introduction}

For the last half-century, the World Health Organization and leading psychiatric associations have been underscoring the reality that without mental health, there can be no true physical health [1]; in its condensed form, this message is simply 'No Health without Mental Health' [2]. There is little question that mental health disorders represent one of the most important public health issues of our time [3,4]. Major depressive disorder (MDD) and anxiety disorders represent debilitating and potentially life-threatening illnesses that are continuing to rise through the ranks of the global burden of diseases [5-7]. Beyond their direct effects, mental disorders contribute to an epidemic of co-morbidity in the form of other non-communicable diseases such as type II diabetes, cardiovascular disease, obesity, and dementia $[8,9]$.

Over the last decade, there has also been increased awareness by both researchers and clinicians that individuals with subthreshold mental health disorders make

Correspondence: aclnd@cfs-fm.org

CAMNR, 23679 Calabasas Road Suite 542, Calabasas, CA 91302, USA up a sizeable portion of patients encountered in primary care settings and that the reported levels of psychological distress, disability in daily activities, and perceived health is often comparable to patients with diagnosable mental disorders [10]. Research shows that those who sit in the subthreshold range of depression are on a trajectory toward higher risk of MDD, dysthymia, social phobia, and generalized anxiety disorder (GAD) [11]. Whether an individual transitions to MDD or not, subthreshold depression is associated with increased demand for healthcare services, non-communicable disease (NCD) co-morbidity, and impaired quality of life [12,13].

It is emphasized here in the introduction that there is much more to mental health than the absence of checklist criteria as found in the Diagnostic and Statistical Manual of Mental Disorders (DSM) and the International Classification of Diseases (ICD). The World Health Organization describes mental health not by the absence of a mental health disorder - rather it is ultimately defined as the ability of an individual to reach their potential in the context of physical and social well-being [14]. The 'No Health without Mental Health' mantra is therefore not a clever 
marketing slogan; it should resonate through all aspects of health promotion.

\section{Roadmap to the current review}

The discipline of physiological anthropology strives to understand the ways in which the modern environment exerts selective pressures on humans, and to what extent those pressures influence physiology and ultimately health and well-being. A growing body of research suggests that modern environmental forces, particularly those that may detract from reaching optimal mental health, are not 'distributed' equally across populations. In addition to understanding how specific variables might influence physiology (for example, dietary patterns or aspects of the built environment), there is a need to explore collective or synergistic pressures and in whom those collective pressures most likely push upon.

The primary destination of the current review is toward the argument that the environmental forces with which vulnerable populations are confronted - many of them at the neighborhood level - might allow dysbiosis to be the norm rather than the exception in those at risk of suboptimal mental health. Dysbiosis, currently defined, involves perturbations to the structure of complex commensal microbial communities. It is a state of change that involves the loss of beneficial microorganisms, and/or the expansion of potentially harmful microbes, and/or the loss of overall microbial diversity [15].

Generally, dysbiosis is accepted to be a shift away from the microbial composition found in 'otherwise healthy adults'. However, just because a healthy adult is accepted as a control subject in various studies (for example, inflammatory bowel disease), it does not mean that they possess the ideal microbial ecosystem. Emerging studies concerning the oral microbiota of our ancestors [16], or the fecal microbiota of our modern relatives that etch out a very traditional, low technological existence [17], have forced questions concerning what truly defines dysbiosis. From the perspective of physiological anthropology, dysbiosis in a modern Westernized nation may indeed be a relative term.

The focus throughout the current discussion will be depressive symptoms and psychological distress. In order to highlight how a 'disparity of microbiota' might unfold, a process referred to later as dysbiotic drift, more detailed discussions of the pathophysiology of depression, the quality of the residential environment (particularly the urban built environment), dietary patterns, and other socioeconomic determinants will be necessary. Central to the unfolding argument will be the emerging evidence suggesting the intestinal (and overall) microbiome - the microbial communities that occupy habitats on and within the body - can shape some degree of mood and behavior in rodents and humans.
The discussion will include the ways in which specific environmental factors might interact with psychological distress in vulnerable populations. Since microbiota can be shaped by environmental forces, it seems reasonable to ask how socioeconomic disparities might influence the microbiota of those that are already in the highest risk category for depression. Although the review will focus largely on depression, the relevance of the discussion may extend to mental health as the WHO defines the term. The reader is encouraged to view the discussion from the vantage point of prevention and early intervention. The lens of prevention can help magnify the importance of various environmental forces that continually push against high-risk populations.

\section{Environmental determinants}

The etiological heterogeneity of depression has been well-described. Although depression can be experienced by any individual, regardless of socioeconomic circumstance, it is a complicated, multi-factorial illness that does not occur randomly in the population. The risk is far higher among the socioeconomically disadvantaged and generally follows a socioeconomic gradient wherein the highest burden of disease is carried by the most impoverished groups [18-22]. Major negative life events have emerged as a distinct neighborhood-health pathway by which context influences risk of depression [23]. On the other hand, daily hassles are also associated with the provocation of depression [24-26], while neighborhood conditions and a collection of chronic lower-grade negative events also push against socioeconomically disadvantaged populations [27-29]. Research indicates that the link between socioeconomic factors and depression may be particularly strong for persistent, chronic depression [30].

Prenatal and early-life stress and other environmentally mediated adversities initiate epigenetic alterations, which in turn may influence lifetime risk of depressive disorders among offspring. Moreover, these environmental factors may also push trans-generational influences via epigenetic inheritance [31]. Both cumulative disadvantage and current socioeconomic hardship are strongly associated with depressive symptoms in adults [32,33]. Research involving twins shows that education, income, and upward social mobility is associated with lowered risk of depression [34].

Social inequalities are also apparent when researchers break down specific psychological assets that otherwise support positive mental health. Optimism in particular has been consistently linked with socioeconomic advantage [35]. In turn, optimism is associated with healthy lifestyle habits [36] and is an independent predictor of good mental health in urban residents [37]. With so much at stake, there is an urgent and obvious need for a deeper understanding of environmental, genetic, and epigenetic determinants of depressive disorders [38]. 


\section{Pathophysiology}

Over time, the collective exposure to physical, social, and psychological stressors can manifest in physiological wear and tear known as allostatic load (AL). The provocation of compensatory physiological mechanisms (for example, immune, cardiovascular, neuroendocrine responses that work well in acute situations) on a repetitive basis can lead to multisystem damage. The AL theory helps to explain how chronic stress can lead to physiological dysregulation and subsequent disease $[39,40]$. In particular, the wear and tear may have detrimental effects on mitochondria [41], the proper functioning of which is intimately connected to mental health [42].

In a bi-directional fashion, $\mathrm{AL}$ predicts compromised mental health [43-46], while individual and area-level socioeconomic disadvantage predicts higher levels of $\mathrm{AL}$ [47-54]. Lifestyle habits such as regular exercise, tobacco abstinence, and healthy dietary patterns are associated with lower AL [55-57]; however, as described in more detail later, these behaviors may be shaped at the neighborhood level.

Despite the etiological heterogeneity of depression, an increasingly robust body of research indicates that there are clear biological dysregulations associated with depressive symptoms and the diagnosis of MDD. These dysregulations are virtually identical to that associated with AI. They include those involving immuno-inflammatory (for example, elevations in C-reactive protein and inflammatory cytokines), metabolic (for example, insulin resistance, metabolic syndrome), the burden of oxidative stress, hypothalamic-pituitary-adrenal (HPA) axis (for example, cortisol perturbations), neurotransmitter/neuropeptide (for example, dopamine, serotonin, gamma-aminobutyric acid, brain-derived neurotrophic factor) communication, and other systems [58,59]. Low-grade inflammation is a central component of emerging psychiatric research because it can help explain the primary biological disturbances currently identified in depression, including those involving neurotransmission $[60,61]$.

In addition to their direct neuro-emotional consequences, these biological dysregulations provide an understanding of the extraordinary relationship between depressive symptoms/MDD and subsequent risk of chronic non-communicable diseases such as cardiovascular disease, obesity, diabetes, and neurodegenerative diseases [58]. Psychosocial stress, well known to be associated with depression [62], can provoke low-grade inflammation; however, once initiated, chronic low-grade inflammation appears well-capable of contributing to further depressive symptoms, cognitive impairment, anxiety, fatigue, sleep problems, and pain [63,64]. Neuroprogression is a term used to describe the cumulative shaping of the central nervous system over time; via pathways of biological dysregulation, this process can mediate the persistence of depression and other mental disorders [65].

Socioeconomic disparities are intimately connected to these known biological dysregulations of depression. Since lower socioeconomic status (SES) is accompanied by chronic psychosocial stress and daily hassles, it is perhaps unsurprising that low SES and neighborhood-level deprivation have been associated with significantly higher biomarkers of AL, including inflammation and oxidative stress [66-69]. Neighborhood-level deprivation and social adversity during the prenatal period is now known to be a distinct risk factor for elevated inflammation in adulthood [70].

Maternal exposure to environmental contaminants (discussed in more detail later) may have detrimental effects on oxytocin signaling [71], a neurohypophysial hormone linked to mood and behavior [72]. A Westernized dietary pattern may also compromise maternal care during the early neonatal period, which in turn may have long-lasting consequences [73]. Neighborhood-level disadvantage is linked to lower diet quality [74]. Moreover, serum antioxidant levels increase with SES at the neighborhood level, which might indicate less physiological burden of oxidative stress and/or increased intake of dietary antioxidants typical of diets rich in fruits and vegetables among the more affluent $[75,76]$. Higher dietary quality in disadvantaged adults is associated with a lower systemic inflammatory burden [77].

\section{Diet and mental health}

Until recently, the relevancy of nutrition to mental health was directed more toward the consequences of gross deficiencies [78]. The notion that more subtle nutrient inadequacies and overall dietary quality could play an important role in mental health was only rarely [79] part of the discourse within mainstream psychiatric literature. Despite clear theoretical mechanisms suggesting that nutrition was an important, yet overlooked, variable [80], psychiatric research remained focused on pharmaceutical interventions and psychological techniques.

However, advances in the emerging field of nutritional psychiatry provide clear evidence that nutrition is an important consideration in short- and long-term neuroemotional health, particularly in depression $[41,81,82]$. The brain is reliant upon amino acids, fats, vitamins and minerals, and trace elements to maintain its functional integrity and high energy demands. Due to this, both macro- and micro-nutritional factors have an important influence on neurocognitive function and mental health. Dietary habits influence the functioning of the immune system (thereby limiting or contributing to low-grade inflammation), sustain the antioxidant defence system, and influence neurotrophic factors that otherwise regulate neuronal growth and plasticity [81]. 
Population studies continue to show that adherence to healthy (sometimes referred to as 'traditional') dietary patterns is associated with lowered risk of depressive symptoms, anxiety, and cognitive decline [83-90]. High-quality perinatal nutrition has been positively associated with mental health outcomes and quality of childhood nutrition with academic performance [91-93]. At the intervention level, short-term adoption of traditional dietary patterns has been shown to have a beneficial influence on mood, cognition, and unresolved fatigue [94-96].

In between the epidemiological work and the emerging intervention studies, there are a host of bench studies. Some demonstrate the divergent influence of Westernized dietary patterns (sometimes described as 'cafeteria' or 'fast food' in animal studies) and traditional diets on behavior and cognition. The former is typically linked to suboptimal cognitive performance and behavioral changes reflective of human anxiety and/or depression [97].

However, because the Westernized dietary pattern is highly palatable, it may attenuate stress and provide a form of 'self-medication' [98-100]; indeed, when animals are withdrawn from a cafeteria diet, there are changes in gene expression governing stress physiology [101]. For humans, this would suggest that a transition off the Westernized diet is itself a stressful experience, perhaps made doubly worse when an individual has been reliant upon the diet to mitigate some level of stress.

The interaction between mood and dietary patterns can be complex [102]; however, there is a collection of research showing that humans often increase their consumption of calorie-dense, nutritionally poor 'comfort foods' when confronted with psychological stress [103-105]. The potential palliative effect of high fat is demonstrated by the direct infusion of fatty acids in the stomach (that is, bypassing visual, olfactory, and gustatory cues); when researchers do so, they can quickly offset an experimentally induced lowered mood state [106]. Whether for psychological [107] and/or physiological reasons, the draw toward unhealthy foods is often strongly associated with chronic depressive symptoms and psychological distress [108-111].

\section{Discounting the future}

Impulsivity has been strongly associated with depression, and it appears to persist even in remission [112]. In order to bridge the gap between discussions of SES and the environmental context (including nutrition and the built environment) described later, it may be worthwhile to briefly describe the relevancy of delay (or temporal) discounting. Volumes of research show that humans often discount the value of future rewards and instead prioritize smaller immediate rewards. Greater discounting has been associated with impulsivity, depression, obesity, and various unhealthy lifestyle habits [113-117].
The slant toward discounting future rewards is also associated with socioeconomic adversities [118,119]. Stress, cognitive load, lowered mood state, and even physical aspects of the built environment (those outside conscious awareness) may magnify delay discounting [120,121]. For example, respondents are much more likely to discount the value of future financial rewards and opt for smaller immediate gains while answering questions in the vicinity of a fast-food outlet [122]. Individuals residing in neighborhoods with higher concentrations of fast-food outlets are more likely to take smaller immediate rewards over larger future gains [122]. The mere presentation of fastfood imagery may provoke impatience and compromise the mood lift that is typically associated with viewing nature scenes [123]. On the other hand, the very aspects of the urban built environment that may be missing in low SES areas - natural vegetation-rich green areas - may help diminish delay discounting [124,125].

\section{Natural environments}

A number of extensive reviews have examined the potential mental health value of natural environments. These are areas typically defined as those that are relatively unchanged or undisturbed by human culture [126], although they can include areas that are designed, manipulated, and sustained by human interventions. In the context of urban settings, this may include gardens, parks, forests, and waterside areas. The reader is directed to detailed reviews covering the ways in which natural environments as whole (and specific elements within them) may buffer stress, improve cognition, facilitate physical activity, encourage social cohesion, and promote overall health and mental well-being [127-129].

A sampling of research shows that greater levels of greenness at the neighborhood level are associated with lower risk of depression and/or anxiety [130-134]. Indeed, one study from New Zealand found that increases in the proportion of useable or total urban green space in proximity to the home was associated with lower rates of anxiety and mood disorder treatment [135]. Mobility research spanning 3 years shows that individuals who move into areas with a higher greenness ( $v s$. their previous residence) experience improved mental health [136].

In the current review, attention is drawn to the increasingly robust research concerning natural environments simply as a means to provide a frame of SES reference for the discussions below. Natural environments may be of particular importance to stress reduction and mental health in socioeconomically disadvantaged neighborhoods wherein higher percentages of green space are linked with healthier daytime salivary cortisol patterns and lower perceived stress $[137,138]$. However, unlike the gradient of depression risk that points toward the disadvantaged, the concentration of urban green space (and/or its perceived 
safety, accessibility, quality) and local biodiversity is often slanted in the opposite direction, favoring the affluent and less vulnerable [139-145]. Indeed, the absence of natural environments in low SES neighborhoods, especially in urban areas, may mean the presence of environmental grey space as described later.

\section{Microbiota and dysbiosis}

Trillions of bacteria (as well as archaea, fungi, protozoa, and viruses) and their genetic material contribute to the human ecosystem. Although it is often stated that the term microbiome is relatively recent, one 'coined' coincidental to the burgeoning use of microbial DNA sequencing technologies, this is untrue. Almost 30 years ago, British scientists wrote: 'A convenient ecological framework in which to examine biocontrol systems is that of the microbiome. This may be defined as a characteristic microbial community occupying a reasonably well defined habitat which has distinct physio-chemical properties. The term thus not only refers to the microorganisms involved but also encompasses their theatre of activity.' [146]. Undoubtedly, microorganisms operating in the human theater of activity, especially the gastrointestinal tract, have been shown to have many distinct physio-chemical properties, including those that may extend to brain structure and function. Emerging evidence suggests that the intestinal microbiota may have a different composition in those with depression $v s$. healthy controls $[147,148]$.

There are multiple pathways by which microbiota may influence brain development, stress physiology, mood, cognition, and behavior. These include, but are not limited to, direct communication with the brain via the vagus nerve, immune-mediated pathways (for example, cytokine production), limitation of oxidative stress, enhancement of nutrient bioavailability and neurotransmitter precursors (for example, tryptophan), and proper maintenance of the gastrointestinal barrier (that is, preventing intestinal permeability and a subsequent cascade of low-grade inflammation) [149]. Although most of the research concerning intestinal microbiota and mental health rests upon rodent studies, a few human studies have provided preliminary evidence that orally administered probiotics or fermented foods may support good mental health [150-156]. The reader is referred to expert reviews for more detail $[157,158]$.

The research concerning microbiota and mental health is highly attractive because it represents a potential link between dietary patterns and environmental considerations. For example, in an experimental study, the transplantation of fecal microbiota from high-fat-diet-fed donor mice into lean mice (raised on standard chow) resulted in altered neurologic function. Interestingly, there were changes in behavior suggestive of anxiety, increased stereotypical behavior, and decreased memory in lean mice upon fecal transfer [159]. Also, the idea that fermented foods may provide enhanced mental health benefit by both direct microbial influence within the intestinal tract and indirect mechanisms through transformation of food chemicals (for example, enhancing nutrient absorption) has been proposed [160].

The lessons learned over the last several decades concerning the hygiene hypothesis - that which suggests the global rise in allergic disease could be related to diminished opportunity for early life exposure to pathogenic microbe exposure via increased hygiene, antibiotics, smaller family sizes, and altered dietary patterns [161,162] suggest that its overarching theme may also extend to neurocognitive and mental health [163,164]. For example, it was recently reported that higher consumption of fermented foods is associated with lower rates of allergy in children [165], a finding that could be related to mental health as described above [160].

Although intestinal microbes are strongly influenced by dietary factors, they are also a product of environmental bacteria [166-168]. Remarkably, the level of green space and biodiversity of vegetation surrounding one's residence has been linked with both diversity of select bacteria on the skin, and lower odds of an allergic IgE reaction to common allergens $[169,170]$. Keeping in mind that environmental biodiversity (for example, variety of plants and birds in a local setting) has been linked to psychological well-being [171-174], it may very well be the case that 'access' to microbial diversity may emerge as a matter of environmental justice.

\section{Grey space and the environmental push}

The preponderance of existing research would suggest that the tripod of healthy dietary habits, diversity of microbiota, and access to quality natural environments are in the best interest of positive mental health. The research also suggests that these are overlapping conversations. For example, closer residential proximity to urban green space and greater park access is associated with healthier dietary habits (for example, more fruits, vegetables, whole grains, nuts/beans, and less fast-food, sodiumrich food, and sugar-rich beverages) and lower insulin resistance [175-177]. In higher population density areas, relatively more natural food/specialty stores, fewer convenience stores, and more physical activity resources are associated with higher diet quality [178]. In socioeconomically disadvantaged neighborhoods, lower levels of open space for physical activity have been linked with greater density of fast-food outlets [179]. It is suggested here that for the most vulnerable (socioeconomically deprived individuals and communities), the odds are stacked against a healthy gut microbiome.

An exercise in visualization may help to crystallize the contention. Imagine residing in a socioeconomically 
deprived community where grey space is the predominant environmental feature. Current research allows for a realistic picture of the dysbiotic environment that might be experienced in this deprived community. At the individual and the neighborhood level, the disparities (and deprivation as a broad term) to be described below may be determined by income, education, social cohesion, racial/ethnic segregation, evaluations of neighborhood esthetic quality, and/or aspects of safety (real and perceived).

It is understood that not all disadvantaged areas are alike; however, the visualized community in this exercise is based largely on how aggregate disadvantage may be encountered in an already developed (Western industrial) nation. As such, it may have some, or even all, of the aforementioned disparities. It is also understood that increases in wealth and socioeconomic status in relation to shifts from traditional lifestyles (along the lines of global trends in diminished contact with biodiversity coincident with urbanization and development) may itself minimize skin and intestinal microbial diversity [180]. However, the discussions here concerning Westernized nations are not without relevance to global regions experiencing a shift from traditional lifestyles and associated increases in wealth [181].

Notwithstanding the heterogeneity of cities, towns, and the neighborhoods in and around them, certain lifestyle habits may be coincident with disadvantage. These may include increased screen time and indoor sedentary behavior [182-187], less sleep [188-190], dietary patterns of high-calorie, low-nutrient-density foods (including ultra-processed, high sodium, additive-rich foods; and/or less fruits and vegetables) [191-196], excess and/or binge alcohol consumption [197,198], and tobacco use [199]. Even if one did not smoke, there would be increased odds of being exposed to second-hand smoke [200].

Whether through changes in dietary patterns and/or less time spent outdoors, the levels of vitamin D might be lower [201-203]. As mentioned earlier, physiological markers such as lower serum carotenoids and red blood cell omega-3 among residents in this neighborhood provides supportive evidence that the absence of highnutrient foods is translating into diminished phytochemical and essential fat intake $[75,76,204]$. In addition, specific nutrients such as magnesium intake may be lower [77], thereby removing a layer of nutritional resiliency. Whether through dietary patterns or other lifestyle variables, rates of functional (chronic idiopathic) constipation would be probably be increased, [205] while the accumulation of advanced glycation end products (AGE) in tissue may be higher [206].

The built environment and elements thereof would be increasing the odds that these lifestyle variables and exposures would remain active and reinforced. Specifically, there would likely be disproportionate industrial and commercial activity, heavy transportation routes, bars, liquor stores, convenience stores, fast-food outlets, and tobacco vendors [207-214]. One might have higher odds of being confronted with visual marketing - for example, billboards, sidewalk signage, targeted screen media delivery - that strongly encourages the maintenance of unhealthy lifestyle choices such as fast-food consumption and tobacco use [215-226]. Grey space is therefore, at least in the opinion of this author, not simply less trees and more concrete; it is a completely divergent mental environment.

Perhaps not surprisingly, brand name logo recognition of major fast-food outlets is notably higher among children in lower SES neighborhoods [227]. The density of fast-food outlets within a neighborhood matters. As much as $31 \%$ of the variance in excessive fast-food consumption may be attributable to simply living in urban areas with moderate or high density of fast-food outlets [228]. Moreover, living in the vicinity of billboard advertising of snacks and sweet drinks is associated with decreased daily fruit or vegetable consumption [229]. In line with the delay discounting research cited above, evidence indicates that food advertising pushes unhealthy food consumption more effectively when cognitive load is high (that is, distracting mental demands). Moreover, those with low SES backgrounds have a lower susceptibility threshold to advertising's effects while under cognitive load [230].

The neighborhood-level availability of healthy food and beverage options may also differ [231-233]. A walk through the retail food environment - whether supermarket or convenience store - may provide a different visual experience regarding shelf space devoted to energy-dense, low-nutrient foods. The internal layout of the stores in this neighborhood may be such that less nutritious foods and beverages dominate, perhaps displacing healthy options [234-238]. The variety of products such as sugar-rich beverages may be higher, their prices lower, and their in-store marketing enhanced [239]. The retail environment may provide a seamless match for targeted screen-media-based marketing toward low-nutrient carbohydrates [240].

Low SES is not only associated with psychological distress, it is a predictor of subsequent distress among individuals with a longer history of psychological distress. Thus, a vicious cycle can ensue whereby psychological distress can become more persistent over time [241]. Higher levels of daily hassles and major forms of psychological stress, combined with fatigue - a key symptom of depression that has been specifically linked to low SES status [242] - may enhance marketing messages in two key ways:

First, there is experimental and human evidence that unhealthy dietary patterns, those inclusive of so-called 
comfort foods, may provide a temporary physiological response that could help mitigate psychological stress [98,243-245]. Even though smoking and beyondmoderate alcohol consumption are ultimately detrimental to mood and act as stressors over time [246], they, like highly palatable dietary items, are also used as a means to mitigate stress $[247,248]$. Second, the appeal of fast-food and ready-to-eat ultra-processed foods (with low-nutrient density) and alcohol could be higher when fatigue, food insecurity, and economic pressures are at the forefront of thought processes [249-253]. In this way, omnipresent marketing messages and the subtle positioning of unhealthy foods within retail settings are like a trap rigged toward the most vulnerable.

The journey through this environment continues. One would also have increased odds of living in a crowded environment $[19,254,255]$, with increased exposure to airborne pollutants [256-258] and other environmental contaminants $[259,260]$. The burden of heat stress would likely be more pronounced [261]. Exposure to aircraft and traffic noise would ensure that acoustic stress is common [262-264], and this problematic noise might, in turn, increase the odds of depression [265] and a prescription for an anxiolytic [266]. In this neighborhood, a visit to a physician could more easily conclude with a prescription for an antibiotic $[267,268]$. The likelihood of carrying elevated numbers of Porphyromonas gingivalis, an oral bacterium connected to periodontal disease, may be higher [269]. Since the environmental burden of light at night (LAN) pollution is increasingly widespread $[270,271]$, it has become difficult to assess if lower SES urban communities are differentially influenced; however, disruption of normal circadian rhythms might be commonplace [272].

\section{Dysbiotic drift}

Now we can turn our attention to the ways in which this environment might push dysbiosis. Human and/or experimental research shows that acute and cumulative psychological stress (and associated markers of allostatic load) [273-276], environmental pollutants [277-282], crowding [283], acoustic stress [284], heat stress [285], Westernized dietary patterns [286], high fructose and sodium [287], dietary AGE and food additives via processed foods $[288,289]$, lack of colorful dietary phytochemicals [290,291], magnesium deficiency [292], inadequate omega-3 [293], antibiotic administration [294], excess alcohol consumption [295,296], the oral periodontopathogen $P$. gingivalis (when swallowed) [297], tobacco exposure [298,299], sedentary behavior [300], circadian disruptions [301], sleep problems with functional constipation [302], and low levels of vitamin D [303,304] are each individually associated with marked shifts in the intestinal microbiota. The increasing use of artificial sweeteners by socioeconomically disadvantaged and minority communities [305] may also promote dysbiosis [306-308].
It becomes plain to see that at virtually every theoretical turn in which dysbiosis could arise, the socioeconomically disadvantaged may be at higher risk (see the 'Dysbiotic forces on a socioeconomic gradient?' section). The collective force of the factors listed above may facilitate a dysbiotic drift among those who have high levels of psychological distress and depressive symptoms. If microbiota are indeed at the intersection of nutrition, environmental health, and lifestyle medicine, as these avenues pertain to mental health, then perhaps it might be time to introduce more detailed discussions of the term disadvantage into the growing gut-brain-microbiota discourse.

\section{Dysbiotic forces on a socioeconomic gradient?}

- Psychological stress

- Processed and ultra-processed foods

- Food additives

- Advanced glycation end products (AGEs)

- Absence of phytochemicals

- Inadequate essential fats

- Inadequate vitamin D

- Inadequate magnesium

- Antibiotic administration

- Potentially pathogenic oral bacteria

- Lack of physical activity/excess indoor screen time

- Tobacco use

- Alcohol use

- Sleep problems/circadian disruptions

- Crowding

- Climatic stress

- Environmental toxins

\section{Summary and future directions}

Despite its obvious ripple into so many aspects of societal health, the 'No Health without Mental Health' dictum is often afforded only lip service by funding bodies [309]. The crisis-level mental health challenges on planet Earth are often given a back-seat to fanciful and fantastical research endeavors [310]. Viewed only superficially, mental health disorders cost well over a trillion (USD) per year in the United States and Europe [311,312]. Add to that the interaction between mental illness, substance abuse, and the bloated criminal justice system, and the costs soar even higher [313,314]. Further add the contribution of mental health disorders (and sub-threshold conditions) toward other burdensome NCDs. Consider still the emerging research on trans-generational outcomes of psychological distress [315], and the financial argument for exploring the brain (in its social-environmentalmicrobial context) becomes painfully obvious.

We are now more than a decade removed from the original (modern era) hypotheses suggesting that the administration of beneficial microbes could have neurocognitive 
[163] and anti-depressant [316] properties. These original hypotheses suggested a potentially modest, adjuvant role for beneficial microbes. Currently, experts suggest that the gut-brain-microbiota axis represents one of the most exciting areas of research to emerge from the neurosciences [317]. At this point it is unclear how (or if) the current body of research will translate into meaningful evidence that can be used by clinicians and policymakers. However, there now seems to be enough background research to at least anticipate downstream questions that could easily arise.

If microbial therapies did provide benefit in mental health, who would be poised to see the most significant gains? How effective would beneficial microbes be when they are used as an attempt to overcome dysbiotic drift? They may have some benefit, but what would be their staying power? Short-term studies will not answer that question. The administration of select beneficial microbes may indeed provide mental health value, perhaps most especially when provided during the perinatal period. However, their true benefit may be obscured when the environmental context in which they are administered remains unchanged.

Therapeutic microbes for health promotion are often thought of as encapsulated probiotics or material ready for pharmaceutical-grade fecal transplant [318]. Massive financial investments are being made to develop drugs that can combat the dysbiotic pathways associated with chronic NCDs [319]. Hopefully, some of these investments will provide returns. Those discussions, however, mostly avoid the topic of the socio-ecological variables that might set up dysbiosis in the first place. Such variables, if greater attention was paid to them, might preclude the need to administer more laboratory-generated drugs directed at the gut microbiome.

A psychobiotic is currently defined as 'a live organism that, when ingested in adequate amounts, produces a health benefit in patients suffering from psychiatric illness' [320]. This is a narrowly defined term for several reasons. First, it restricts organisms to their live state. Recent human data, however, shows that heat-inactivated microbes can influence immunity [321] and promote mental health (reduction of tension-anxiety) [322]. Second, it bypasses the notion of prevention and utility in those who might sit under diagnostic criteria (that is, well individuals or those who may not be suffering from an overt psychiatric illness, yet not in optimal mental health as the WHO see it). Third, the definition restricts to ingestion (that is, does not consider inhalation and/or cutaneous routes of influence [323]). Fourth, the term provides no obvious link to the basis of much of the discussion here in this review internal and external ecosystems. It could be argued that -biotic attached to the prefix eco- would be a better choice; however, that term is now firmly entrenched in commercial trademarked microbial products, and furthermore, it makes no reference to mental health specificity.

The term eco-psychotropic may capture the broad lens from which this topic might be viewed. Eco-psychotropics include any microorganisms, or parts thereof, that can benefit human ecosystems and/or physiology in the promotion of mental health. This allows for both pharmaceuticaloriented discussions and wide-ranging dialogue whereby the deprivation of eco-psychotropics considers natural environments and more upstream attempts to address the environmental forces that push toward dysbiosis. Eco-psychotropics could be living and non-living microbes carried within fermented foods; yet they may also be defined as the microbial agents that transform foods during fermentation such that they (the food items) are more capable of promoting mental health [160]. Activities such as community gardening [324], or spending time in natural environments [164], may place one in contact with eco-psychotropics.

Patents, broad intellectual property claims, and commercial interests could easily direct the gut-brain-microbiota research juggernaut toward single microbe/microbial product solutions. The enthusiasm of the psychopharmacologist who might view encapsulated products as a microbial fluoxetine or alprazolam is understandable. Nonetheless, if such directed developments in research are viewed distinctly from glaring environmental factors (socioeconomic, ecological, marketing forces, and otherwise), it might overestimate the potential value of therapeutic outcomes, particularly in the most vulnerable.

There seems little question that environmental factors are upstream and modifiable variables on the course toward sub-threshold and diagnosable mental health disorders. There is no evidence, at least in North America, that the rates of psychological distress are declining $[325,326]$. Given that medication and psychotherapy interventions provide only modest benefit, and estimated value may be over-inflated by publication bias [327-333], a new frontier of therapeutic hope, one that might act in synergy with first-line interventions, is most welcome. Emerging studies in the clinical setting will undoubtedly help to provide much needed evidence to guide policy and practice [334].

The young science of the microbiome-brain connection has established that microbes matter. If this area of research is to fulfill all of its promise, there must surely be a turn toward the exploration of its relevancy within socioeconomic and other environmental contexts. To date, the words socioeconomic, disadvantaged, deprived, and vulnerable have largely escaped discourse within the emerging studies and primary reviews; medical news stories suggest that the field is turning its attention toward precise clinical evaluations of probiotics in mental health [335]. Now might be an appropriate time to 
broaden the dialogue with an eye toward who might have those most to gain (or, conversely, those who are likely to gain the least).

Differences in oral salivary microbiota have been noted along socioeconomic lines [336]. It would be interesting to know if there are distinctions in the oral, intestinal, and/or skin microbiota that exist along a neighborhood SES gradient. If so, are those distinctions connected to features of the natural (or built) environment and/or mental well-being?

Many Charters and Constitutions now set forth that humans have a fundamental right to live in an environment that supports their overall health and well-being [337]. Environment is obviously a broad term. It could be argued that an environment filled with visual and auditory cajoling toward unhealthy lifestyle behaviors is at odds with this fundamental right. It could be theorized that diversity of unseen biotic elements - including nonpathogenic microbes - are an essential environmental component in the support of health and well-being; and by extension, the grey space factors that might contribute to dysbiotic drift would also be at odds with this right.

\section{Competing interests}

ACL has received consulting fees from Genuine Health Inc (Toronto, ON, Canada).

Received: 5 March 2015 Accepted: 23 April 2015

Published online: 07 May 2015

\section{References}

1. Kolappa K, Henderson DC, Kishore SP. No physical health without mental health: lessons unlearned? Bull World Health Org. 2013;91:3-3.

2. Prince M, Patel V, Saxena S, Maj M, Maselko J, Phillips MR, et al. No health without mental health. Lancet. 2007;370:859-77.

3. Murray CJ, Vos T, Lozano R, Naghavi M, Flaxman AD, Michaud C, et al. Disability-adjusted life years (DALYs) for 291 diseases and injuries in 21 regions, 1990-2010: a systematic analysis for the Global Burden of Disease Study 2010. Lancet. 2012;380:2197-223.

4. Whiteford HA, Ferrari AJ, Degenhardt L, Feigin V, Vos T. The global burden of mental, neurological and substance use disorders: an analysis from the global burden of disease study 2010. PLoS One. 2015;10:e0116820.

5. Yang $G$, Wang $Y$, Zeng $Y$, Gao GF, Liang $X$, Zhou M, et al. Rapid health transition in China, 1990-2010: findings from the Global Burden of Disease Study 2010. Lancet. 2013;381:1987-2015.

6. Lee KS, Park JH. Burden of disease in Korea during 2000-10. J Public Health. 2014 In Press

7. Mokdad AH, Jaber S, Aziz Ml, AlBuhairan F, AlGhaithi A, AlHamad NM, et al. The state of health in the Arab world, 1990-2010: an analysis of the burden of diseases, injuries, and risk factors. Lancet. 2014;383:309-20.

8. Sartorius N, Cimino L. The co-occurrence of diabetes and depression: an example of the worldwide epidemic of comorbidity of mental and physical illness. Ann Acad Med Singapore. 2012;41:430-1.

9. Lin CH, Lee YY, Liu CC, Chen HF, Ko MC, Li CY. Urbanization and prevalence of depression in diabetes. Public Health. 2012;126:104-11.

10. Rucci P, Gherardi S, Tansella M, Piccinelli M, Berardi D, Bisoffi G, et al. Subthreshold psychiatric disorders in primary care: prevalence and associated characteristics. J Affect Disord. 2003;76:171-81.

11. Pietrzak RH, Kinley J, Afifi TO, Enns MW, Fawcett J, Sareen J. Subsyndromal depression in the United States: prevalence, course, and risk for incident psychiatric outcomes. Psychol Med. 2013;43:1401-14.

12. Goldney RD, Fisher L, Dal Grande E, Taylor AW. Subsyndromal depression: prevalence, use of health services and quality of life in an Australian population. Soc Psychiatry Psychiatr Epidemiol. 2004;39:293-8.
13. Rodríguez MR, Nuevo R, Chatterji S, Ayuso-Mateos JL. Definitions and factors associated with subthreshold depressive conditions: a systematic review. BMC Psychiatry. 2012;12:181.

14. World Health Organization: Mental health: strengthening our response. WHO Fact Sheet N²20. 2014.

15. Petersen C, Round JL. Defining dysbiosis and its influence on host immunity and disease. Cell Microbiol. 2014;16:1024-33.

16. Warinner C, Speller C, Collins MJ. A new era in palaeomicrobiology: prospects for ancient dental calculus as a long-term record of the human oral microbiome. Philos Trans R Soc Lond B Biol Sci. 2015;370(1660):20130376.

17. Obregon-Tito AJ, Tito RY, Metcalf J, Sankaranarayanan K, Clemente JC, Ursell $L K$, et al. Subsistence strategies in traditional societies distinguish gut microbiomes. Nat Commun. 2015;6:6505.

18. Allen J, Balfour R, Bell R, Marmot M. Social determinants of mental health. Int Rev Psychiatry. 2014;26:392-407.

19. Coutinho LM, Matijasevich A, Scazufca M, Menezes PR. Prevalence of common mental disorders and the relationship to the social context: multilevel analysis of the São Paulo Ageing \& Health Study (SPAH). Cad Saude Publica. 2014;30:1875-83.

20. Blair A, Ross NA, Gariepy G, Schmitz N. How do neighborhoods affect depression outcomes? A realist review and a call for the examination of causal pathways. Soc Psychiatry Psychiatr Epidemiol. 2014;49:873-87.

21. Williams ED, Tillin T, Richards M, Tuson C, Chaturvedi N, Hughes AD, Stewart R. Depressive symptoms are doubled in older British South Asian and Black Caribbean people compared with Europeans: associations with excess co-morbidity and socioeconomic disadvantage. Psychol Med. 2015 In Press

22. Hsu CY, Chang SS, Lee ES, Yip PS. Geography of suicide in Hong Kong: Spatial patterning, and socioeconomic correlates and inequalities. Soc Sci Med. 2015;130C:190-203.

23. King K, Ogle C. Negative life events vary by neighborhood and mediate the relation between neighborhood context and psychological well-being. PLoS One. 2014;9:e93539.

24. Mechakra-Tahiri DS, Dubé $M$, Zunzunegui MV, Préville $M$, Berbiche $D$, Brassard J. Pattern of change of depressive disorder over a one-year period among community-dwelling older adults in Québec. Depress Res Treat. 2013;2013:451708.

25. ten Doesschate MC, Bockting CL, Koeter MW, Schene AH, DELTA. Study Group. Prediction of recurrence in recurrent depression: a 5.5-year prospective study. J Clin Psychiatry. 2010;71:984-91.

26. Mair CA, Cutchin MP, Kristen PM. Allostatic load in an environmental riskscape: the role of stressors and gender. Health Place. 2011;17:978-87.

27. Jacob R, Arnold LD, Hunleth J, Greiner KA, James AS. Daily hassles' role in health seeking behavior among low-income populations. Am J Health Behav. 2014;38:297-306.

28. Vinkers CH, Joëls M, Milaneschi Y, Kahn RS, Penninx BW, Boks MP. Stress exposure across the life span cumulatively increases depression risk and is moderated by neuroticism. Depress Anxiety. 2014;31(9):737-45.

29. Clarke P, Morenoff J, Debbink M, Golberstein E, Elliott MR, Lantz PM. Cumulative exposure to neighborhood context: consequences for health transitions over the adult life course. Res Aging. 2014;36:115-42.

30. Melchior M, Chastang JF, Head J, Goldberg M, Zins M, Nabi H, et al. Socioeconomic position predicts long-term depression trajectory: a 13-year follow-up of the GAZEL cohort study. Mol Psychiatry. 2013;18:112-21.

31. Babenko O, Kovalchuk I, Metz GA. Stress-induced perinatal and transgenerational epigenetic programming of brain development and mental health. Neurosci Biobehav Rev. 2015:48C:70-91.

32. van der Waerden JE, Hoefnagels C, Hosman CM, Jansen MW. Defining subgroups of low socioeconomic status women at risk for depressive symptoms: the importance of perceived stress and cumulative risks. Int J Soc Psychiatry. 2014;60:772-82.

33. Nicholson A, Pikhart H, Pajak A, Malyutina S, Kubinova R, Peasey A, et al. Socio-economic status over the life-course and depressive symptoms in men and women in Eastern Europe. J Affect Disord. 2008;105:125-36.

34. Mezuk B, Myers JM, Kendler KS. Integrating social science and behavioral genetics: testing the origin of socioeconomic disparities in depression using a genetically informed design. Am J Public Health. 2013;103 Suppl 1:S145-51.

35. Boehm JK, Chen Y, Williams DR, Ryff C, Kubzansky LD. Unequally distributed psychological assets: are there social disparities in optimism, life satisfaction, and positive affect? PLoS One. 2015;10:e0118066. 
36. Boehm JK, Williams DR, Rimm EB, Ryff C, Kubzansky LD. Association between optimism and serum antioxidants in the midlife in the United States study. Psychosom Med. 2013;75:2-10.

37. Tsuno YS, Yamazaki Y. Relationships among sense of coherence, resources, and mental health in urban and rural residents in Japan. BMC Public Health. 2012;12:1107.

38. Dunn EC, Brown RC, Dai Y, Rosand J, Nugent NR, Amstadter AB, et al. Genetic determinants of depression: recent findings and future directions. Harv Rev Psychiatry. 2015;23:1-18.

39. Beckie TM. A systematic review of allostatic load, health, and health disparities. Biol Res Nurs. 2012;14:311-46.

40. Barboza Solís C, Kelly-Irving M, Fantin R, Darnaudéry M, Torrisani J, Lang T, Delpierre C. Adverse childhood experiences and physiological wear-and-tear in midlife: Findings from the 1958 British birth cohort. Proc Natl Acad Sci U S A. 2015 In Press

41. Picard M, Juster RP, McEwen BS. Mitochondrial allostatic load puts the 'gluc' back in glucocorticoids. Nat Rev Endocrinol. 2014;10:303-10.

42. Kaplan BJ, Rucklidge JJ, Romijn R, McLeod K. The emerging field of nutritional mental health: inflammation, the microbiome, oxidative stress, and mitochondrial function. Clin Psychol Sci. 2015 In Press

43. Kobrosly RW, van Wijngaarden E, Seplaki CL, Cory-Slechta DA, Moynihan J. Depressive symptoms are associated with allostatic load among community-dwelling older adults. Physiol Behav. 2014;123:223-30.

44. Kobrosly RW, Seplaki CL, Cory-Slechta DA, Moynihan J, van Wijngaarden E. Multisystem physiological dysfunction is associated with depressive symptoms in a population-based sample of older adults. Int J Geriatr Psychiatry. 2013;28:718-27.

45. Buss KA, Davis EL, Kiel EJ. Allostatic and environmental load in toddlers predicts anxiety in preschool and kindergarten. Dev Psychopathol. 2011:23:1069-87.

46. Peskin M, Raine A, Gao Y, Venables PH, Mednick SA. A developmental increase in allostatic load from ages 3 to 11 years is associated with increased schizotypal personality at age 23 years. Dev Psychopathol. 2011:23:1059-68

47. Robertson T, Benzeval M, Whitley E, Popham F. The role of material, psychosocial and behavioral factors in mediating the association between socioeconomic position and allostatic load (measured by cardiovascular, metabolic and inflammatory markers). Brain Behav Immun. 2014 In Press

48. Gustafsson PE, San Sebastian M, Janlert U, Theorell T, Westerlund H, Hammarström A. Life-course accumulation of neighborhood disadvantage and allostatic load: empirical integration of three social determinants of health frameworks. Am J Public Health. 2014;104:904-10.

49. Slopen N, Non A, Williams DR, Roberts AL, Albert MA. Childhood adversity, adult neighborhood context, and cumulative biological risk for chronic diseases in adulthood. Psychosom Med. 2014;76:481-9.

50. Brody GH, Lei MK, Chen E, Miller GE. Neighborhood poverty and allostatic load in African American youth. Pediatrics. 2014;134:e1362-8.

51. Theall KP, Drury SS, Shirtcliff EA. Cumulative neighborhood risk of psychosocial stress and allostatic load in adolescents. Am J Epidemiol. 2012;176 Suppl 7:S164-74.

52. Gruenewald TL, Karlamangla AS, Hu P, Stein-Merkin S, Crandall C, Koretz B, et al. History of socioeconomic disadvantage and allostatic load in later life. Soc Sci Med. 2012;74:75-83.

53. Schulz AJ, Mentz G, Lachance L, Zenk SN, Johnson J, Stokes C, et al. Do observed or perceived characteristics of the neighborhood environment mediate associations between neighborhood poverty and cumulative biological risk? Health Place. 2013:24:147-56.

54. Schulz AJ, Mentz G, Lachance L, Johnson J, Gaines C, Israel BA. Associations between socioeconomic status and allostatic load: effects of neighborhood poverty and tests of mediating pathways. Am J Public Health. 2012;102:1706-14.

55. Rosenberg N, Park CG, Eldeirawi K. Relationship of serum carotenoid concentrations with allostatic load as a measure of chronic stress among middle-aged adults in the USA. Public Health Nutr. 2014;11:1-9.

56. Mattei J, Bhupathiraju S, Tucker KL. Higher adherence to a diet score based on American Heart Association recommendations is associated with lower odds of allostatic load and metabolic syndrome in Puerto Rican adults. J Nutr. 2013;143:1753-9.

57. Gay JL, Salinas JJ, Buchner DM, Mirza S, Kohl HW 3rd, Fisher-Hoch SP, McCormick JB. Meeting physical activity guidelines is associated with lower allostatic load and inflammation in Mexican Americans. J Immigr Minor Health. 2014 In Press
58. Penninx BW, Milaneschi Y, Lamers F, Vogelzangs N. Understanding the somatic consequences of depression: biological mechanisms and the role of depression symptom profile. BMC Med. 2013;11:129.

59. Wium-Andersen MK, Ørsted DD, Nielsen SF, Nordestgaard BG. Elevated C-reactive protein levels, psychological distress, and depression in 73, 131 individuals. JAMA Psychiatry. 2013;70:176-84.

60. Leonard BE. Impact of inflammation on neurotransmitter changes in major depression: an insight into the action of antidepressants. Prog Neuropsychopharmacol Biol Psychiatry. 2014;48:261-7.

61. Lasselin J, Capuron L. Chronic low-grade inflammation in metabolic disorders: relevance for behavioral symptoms. Neuroimmunomodulation. 2014;21:95-101.

62. Roca M, Gili M, Garcia-Campayo J, Armengol S, Bauza N, García-Toro M Stressful life events severity in patients with first and recurrent depressive episodes. Soc Psychiatry Psychiatr Epidemiol. 2013;48:1963-9.

63. Rohleder N. Stimulation of systemic low-grade inflammation by psychosocial stress. Psychosom Med. 2014;76:181-9.

64. Berk M, Williams $\sqcup$, Jacka FN, O'Neil A, Pasco JA, Moylan S, et al. So depression is an inflammatory disease, but where does the inflammation come from? BMC Med. 2013;11:200

65. Walker AJ, Kim Y, Price JB, Kale RP, McGillivray JA, Berk M, et al. Stress, inflammation, and cellular vulnerability during early stages of affective disorders: biomarker strategies and opportunities for prevention and intervention. Front Psychiatry. 2014;5:34.

66. Fraga S, Marques-Vidal P, Vollenweider P, Waeber G, Guessous I, Paccaud F, et al. Association of socioeconomic status with inflammatory markers: A two cohort comparison. Prev Med. 2014;71C:12-9.

67. Stringhini S, Batty GD, Bovet P, Shipley MJ, Marmot MG, Kumari M, et al. Association of lifecourse socioeconomic status with chronic inflammation and type 2 diabetes risk: the Whitehall II prospective cohort study. PLoS Med. 2013;10:e1001479.

68. Keita AD, Judd SE, Howard VJ, Carson AP, Ard JD, Fernandez JR. Associations of neighborhood area level deprivation with the metabolic syndrome and inflammation among middle- and older- age adults. BMC Public Health. 2014;14:1319.

69. Nazmi A, Diez Roux A, Ranjit N, Seeman TE, Jenny NS. Cross-sectional and longitudinal associations of neighborhood characteristics with inflammatory markers: findings from the multi-ethnic study of atherosclerosis. Health Place. 2010;16:1104-12.

70. Slopen N, Loucks EB, Appleton AA, Kawachi I, Kubzansky LD, Non AL, et al. Early origins of inflammation: An examination of prenatal and childhood social adversity in a prospective cohort study. Psychoneuroendocrinology. 2015;51:403-13.

71. Win-Shwe TT, Fujitani Y, Kyi-Tha-Thu C, Furuyama A, Michikawa T, Tsukahara $S$, et al. Effects of diesel engine exhaust origin secondary organic aerosols on novel object recognition ability and maternal behavior in BALB/c mice. Int J Environ Res Public Health. 2014;11:11286-307.

72. McQuaid RJ, McInnis OA, Abizaid A, Anisman H. Making room for oxytocin in understanding depression. Neurosci Biobehav Rev. 2014;45:305-22.

73. Connor KL, Vickers MH, Beltrand J, Meaney MJ, Sloboda DM. Nature, nurture or nutrition? Impact of maternal nutrition on maternal care, offspring development and reproductive function. J Physiol. 2012;590:2167-80.

74. Keita AD, Casazza K, Thomas O, Fernandez JR. Neighborhood-level disadvantage is associated with reduced dietary quality in children. J Am Diet Assoc. 2009;109:1612-6.

75. Nicklett EJ, Szanton S, Sun K, Ferrucci L, Fried LP, Guralnik JM, et al. Neighborhood socioeconomic status is associated with serum carotenoid concentrations in older, community-dwelling women. J Nutr. 2011;141:284-9.

76. Stimpson JP, Nash AC, Ju H, Eschbach K. Neighborhood Deprivation is associated with lower levels of serum carotenoids among adults participating in the Third National Health and Nutrition Examination Survey. J Am Diet Assoc. 2007;107:1895-902.

77. Kuczmarski MF, Mason MA, Allegro D, Zonderman AB, Evans MK. Diet quality is inversely associated with C-reactive protein levels in urban low-income African-American and white adults. J Acad Nutr Diet. 2013;113:1620-31.

78. Brown AS, van Os J, Driessens C, Hoek HW, Susser ES. Further evidence of relation between prenatal famine and major affective disorder. Am J Psychiatry. 2000;157:190-5.

79. Gelenberg A. Nutrition in psychiatry: we are what we eat? J Clin Psychiatry. 1980;41:328-9. 
80. Horrobin D. Food, micronutrients, and psychiatry. Int Psychogeriatr. 2002;14:331-4.

81. Sarris J, Logan AC, Akbaraly TN, Amminger P, Balanzá-Martínez, V, Freeman MP, Hibbeln J, Matsuoka Y, Mischoulon D, Mizuoue T, Nanri A, Nishi D, Ramsey D, Rucklidge J, Sanchez-Villegas A, Scholey A, Su K-P, Jacka FN. Nutritional medicine as mainstream in psychiatry. Lancet Psychiatry. 2015, In Press

82. Logan $A C$, Jacka FJ. Nutritional psychiatry research: an emerging discipline and its intersection with global urbanization, environmental challenges, and the evolutionary mismatch. J Physiol Anthropol. 2014;33:22.

83. Jacka FN, Mykletun A, Berk M, Bjelland I, Tell GS. The association between habitual diet quality and the common mental disorders in community-dwelling adults: the Hordaland Health study. Psychosom Med. 2011;73:483-90.

84. Jacka FN, Pasco JA, Mykletun A, Williams LJ, Hodge AM, O'Reilly SL, et al. Association of Western and traditional diets with depression and anxiety in women. Am J Psychiatry. 2010;167:305-11

85. Sánchez-Villegas A, Delgado-Rodríguez M, Alonso A, Schlatter J, Lahortiga F, Serra Majem L, et al. Association of the Mediterranean dietary pattern with the incidence of depression: the Seguimiento Universidad de Navarra/ University of Navarra follow-up (SUN) cohort. Arch Gen Psychiatry. 2009;66:1090-8.

86. Skarupski KA, Tangney CC, Li H, Evans DA, Morris MC. Mediterranean diet and depressive symptoms among older adults over time. J Nutr Health Aging. 2013;17:441-5.

87. Rienks J, Dobson AJ, Mishra GD. Mediterranean dietary pattern and prevalence and incidence of depressive symptoms in mid-aged women: results from a large community-based prospective study. Eur J Clin Nutr. 2013:67:75-82.

88. Lai JS, Hiles S, Bisquera A, Hure AJ, McEvoy M, Attia J. A systematic review and meta-analysis of dietary patterns and depression in community-dwelling adults. Am J Clin Nutr. 2014;99:181-97.

89. Psaltopoulou T, Sergentanis TN, Panagiotakos DB, Sergentanis IN, Kosti R, Scarmeas N. Mediterranean diet, stroke, cognitive impairment, and depression: a meta-analysis. Ann Neurol. 2013;74:580-91.

90. Flórez KR, Dubowitz T, Ghosh-Dastidar MB, Beckman R, Collins RL. Associations between depressive symptomatology, diet, and body mass index among participants in the Supplemental Nutrition Assistance Program. J Acad Nutr Diet. 2015 Mar 6. pii: S2212-2672(15)00002-7.

91. Jacka FN, Ystrom E, Brantsaeter AL, Karevold E, Roth C, Haugen M, et al. Maternal and early postnatal nutrition and mental health of offspring by age 5 years: a prospective cohort study. J Am Acad Child Adolesc Psychiatry. 2013:52:1038-47.

92. Pina-Camacho L, Jensen SK, Gaysina D, Barker ED. Maternal depression symptoms, unhealthy diet and child emotional-behavioural dysregulation. Psychol Med. 2014 In Press

93. Purtell KM, Gershoff ET. Fast food consumption and academic growth in late childhood. Clin Pediatr. 2014 In Press

94. Lee, J, Pase M, Pipingas A, Raubenheimer J, Thurgood M, Villalon L, MacPherson H, Gibbs A, Scholey A. Switching to a 10-day Mediterranean-style diet improves mood and cardiovascular function in a controlled crossover study. Nutr. 2015 In Press

95. McMillan L, Owen L, Kras M, Scholey A. Behavioural effects of a 10-day Mediterranean diet. Results from a pilot study evaluating mood and cognitive performance Appetite. 2011;56(1):143-7.

96. Steenbruggen TG, Hoekstra SJ, van der Gaag EJ. Could a change in diet revitalize children who suffer from unresolved fatigue? Nutrients. 2015;7(3):1965-77.

97. Hill JO, Berridge K, Avena NM, Ziauddeen H, Alonso-Alonso M, Allison DB, et al. Neurocognition: the food-brain connection. Adv Nu. 2014;5:544-6.

98. Zeeni N, Bassil M, Fromentin G, Chaumontet C, Darcel N, Tome D, et al. Environmental enrichment and cafeteria diet attenuate the response to chronic variable stress in rats. Physiol Behav. 2015;139:41-9.

99. Garber AK, Lustig RH. Is fast food addictive? Curr Drug Abuse Rev. 2011;4:146-62.

100. Maniam J, Morris MJ. Palatable cafeteria diet ameliorates anxiety and depression-like symptoms following an adverse early environment. Psychoneuroendocrinology. 2010;35:717-28.

101. Martire SI, Maniam J, South T, Holmes N, Westbrook RF, Morris MJ. Extended exposure to a palatable cafeteria diet alters gene expression in brain regions implicated in reward, and withdrawal from this diet alters gene expression in brain regions associated with stress. Behav Brain Res. 2014;265:132-41.
102. Jacka FN, Cherbuin N, Anstey KJ, Butterworth P. Does reverse causality explain the relationship between diet and depression? J Affect Disord. 2015;175C:248-50.

103. Michels N, Sioen I, Braet C, Huybrechts I, Vanaelst B, Wolters M, et al. Relation between salivary cortisol as stress biomarker and dietary pattern in children. Psychoneuroendocrinology. 2013;38:1512-20.

104. Weltens N, Zhao D, Van Oudenhove L. Where is the comfort in comfort foods? Mechanisms linking fat signaling, reward, and emotion. Neurogastroenterol Motil. 2014;6:303-15.

105. Tryon MS, Carter CS, Decant R, Laugero KD. Chronic stress exposure may affect the brain's response to high calorie food cues and predispose to obesogenic eating habits. Physiol Behav. 2013;120:233-42.

106. Van Oudenhove L, McKie S, Lassman D, Uddin B, Paine P, Coen S, et al. Fatty acid-induced gut-brain signaling attenuates neural and behavioral effects of sad emotion in humans. J Clin Invest. 2011;121:3094-9.

107. Wagner H, Ahlstrom B, Redden J, Vickers Z, Mann T. The myth of comfort food. Health Psychol. 2014;33:1552-7.

108. Sánchez-Villegas A, Toledo E, de Irala J, Ruiz-Canela M, Pla-Vidal J, Martínez González MA. Fast-food and commercial baked goods consumption and the risk of depression. Public Health Nutr. 2012;15:424-32.

109. Vilija M, Romualdas M. Unhealthy food in relation to posttraumatic stress symptoms among adolescents. Appetite. 2014;74:86-91.

110. Crawford GB, Khedkar A, Flaws JA, Sorkin JD, Gallicchio L. Depressive symptoms and self-reported fast-food intake in midlife women. Prev Med. 201 1;52:254-7.

111. Hirth JM, Rahman M, Berenson AB. The association of posttraumatic stress disorder with fast food and soda consumption and unhealthy weight loss behaviors among young women. J Womens Health. 2011;20:1141-9.

112. Saddichha S, Schuetz C. Impulsivity in remitted depression: a meta-analytical review. Asian J Psychiatr. 2014;9:13-6.

113. Pulcu E, Trotter PD, Thomas EJ, McFarquhar M, Juhasz G, Sahakian BJ, et al. Temporal discounting in major depressive disorder. Psychol Med. 2013;1:1-10

114. Lu Q, Tao F, Hou F, Zhang Z, Sun Y, Xu Y, et al. Cortisol reactivity, delay discounting and percent body fat in Chinese urban young adolescents. Appetite. 2014;72:13-20.

115. Imhoff S, Harris M, Weiser J, Reynolds B. Delay discounting by depressed and non-depressed adolescent smokers and non-smokers. Drug Alcohol Depend. 2014;135:152-5.

116. Jarmolowicz DP, Cherry JB, Reed DD, Bruce JM, Crespi JM, Lusk JL, et al. Robust relation between temporal discounting rates and body mass Appetite. 2014;78:63-7.

117. Story GW, Vlaev I, Seymour B, Darzi A, Dolan RJ. Does temporal discounting explain unhealthy behavior? A systematic review and reinforcement learning perspective Front Behav Neurosci. 2014;8:76.

118. Lovallo WR, Farag NH, Sorocco KH, Acheson A, Cohoon AJ, Vincent AS. Early life adversity contributes to impaired cognition and impulsive behavior: studies from the Oklahoma Family Health Patterns Project. Alcohol Clin Exp Res. 2013;37:616-23.

119. Acheson A, Vincent AS, Sorocco KH, Lovallo WR. Greater discounting of delayed rewards in young adults with family histories of alcohol and drug use disorders: studies from the Oklahoma family health patterns project. Alcohol Clin Exp Res. 2011;35:1607-13.

120. Fields SA, Lange K, Ramos A, Thamotharan S, Rassu F. The relationship between stress and delay discounting: a meta-analytic review. Behav Pharmacol. 2014;25:434-44

121. Gardner MP, Wansink B, Kim J, Park SB. Better moods for better eating? How mood influences food choice. J Consumer Psychol. 2014;24:320-35.

122. DeVoe SE, House J, Zhong CB. Fast food and financial impatience: a socioecological approach. J Pers Soc Psychol. 2013;105:476-94.

123. House J, DeVoe SE, Zhong CB. Too impatient to smell the roses: exposure to fast food impedes happiness. Soc Psychol Personality Sci. 2014;5:534-41.

124. van der Wal AJ, Schade HM, Krabbendam L, van Vugt M. Do natural landscapes reduce future discounting in humans? Proc Biol Sci. 2013;280:20132295.

125. Berry MS, Sweeney MM, Morath J, Odum AL, Jordan KE. The nature of impulsivity: visual exposure to natural environments decreases impulsive decision-making in a delay discounting task. PLoS One. 2014;9:e97915.

126. Johnson DL, Ambrose SH, Bassett TJ, Bowen ML, Cummey DE, Isaacson JS, et al. Meanings of environmental terms. J Environ Qual. 1997;26:581-9.

127. Logan AC, Katzman MA, Balanzá-Martínez V. Natural environments, ancestral diets, and microbial ecology: is there a modern "paleo-deficit disorder"? Part I J Physiol Anthropol. 2015;34:1. 
128. Triguero-Mas M, Dadvand P, Cirach M, Martínez D, Medina A, Mompart A, et al. Natural outdoor environments and mental and physical health: relationships and mechanisms. Environ Int. 2015;77C:35-41.

129. Berto R. The role of nature in coping with psycho-physiological stress: a literature review on restorativeness. Behav Sci. 2014;4:394-409.

130. Gariepy G, Kaufman JS, Blair A, Kestens Y, Schmitz N. Place and health in diabetes: the neighbourhood environment and risk of depression in adults with Type 2 diabetes. Diabetic Med. 2015 In Press

131. Maas J, Verheij RA, de Vries S, Spreeuwenberg P, Schellevis FG, Groenewegen PP. Morbidity is related to a green living environment. J Epidemiol Community Health. 2009;63:967-73.

132. Beyer K, Kaltenbach A, Szabo A, Bogar S, Nieto FJ, Malecki KM. Exposure to neighborhood green space and mental health. Int J Environ Public Health Res. 2014;11:3453-72.

133. Bodicoat DH, O'Donovan G, Dalton AM, Gray LJ, Yates T, Edwardson C, et al. The association between neighbourhood greenspace and type 2 diabetes in a large cross-sectional study. BMJ Open. 2014;4:e006076.

134. Cohen-Cline H, Turkheimer E, Duncan GE. Access to green space, physical activity and mental health: a twin study. J Epidemiol Community Health. 2015 In Press

135. Nutsford D, Pearson AL, Kingham S. An ecological study investigating the association between access to urban green space and mental health. Public Health. 2013;127:1005-11.

136. Alcock I, White MP, Wheeler BW, Fleming LE, Depledge MH. Longitudinal effects on mental health of moving to greener and less green urban areas. Environ SciTechnol. 2014;48:1247-55.

137. Thompson CW, Roe J, Aspinall P, Mitchell R, Clow A, Miller D. More green space is linked to less stress in deprived communities: evidence from salivary cortisol patterns. Landscape Urban Plan. 2012;105:221-9.

138. Roe JJ, Thompson CW, Aspinall PA, Brewer MJ, Duff El, Miller D, et al. Green space and stress: evidence from cortisol measures in deprived urban communities. Int J Environ Res Public Health. 2013;10:4086-103.

139. Jennings V, Gaither CJ. Approaching environmental health disparities and green spaces: an ecosystem services perspective. Int J Environ Res Public Health. 2015;12:1952-68.

140. Dobbs C, Nitschke CR, Kendal D. Global drivers and tradeoffs of three urban vegetation ecosystem services. PLoS One. 2014;9:e113000.

141. Clarke LW, Jenerette GD, Davilla A. The luxury of vegetation and the legacy of tree biodiversity in Los Angeles. CA Landscape Urban Plan. 2013;116:48-59.

142. Heynen N, Perkins HA, Roy P. The Political Ecology of Uneven Urban Green Space: the impact of political economy on race and ethnicity in producing environmental inequality in Milwaukee. Urban Aff Rev. 2006;42:3-25.

143. van Heezik Y, Freeman C, Porter S, Dickinson K. Garden size, householder knowledge, and socio-economic status influence plant and bird diversity at the scale of individual gardens. Ecosystems. 2013;16:1442-54.

144. Rigolon A, Flohr TL. Access to parks for youth as an environmental justice issue: access inequalities and possible solutions. Buildings. 2014;4:69-94.

145. Schwarz K, Fragkias M, Boone CG, Zhou W, McHale M, Grove JM, et al. Trees grow on money: urban tree canopy cover and environmental justice. PLoS One. 2015;10(4):e0122051.

146. Whipps JM, Karen L, Cooke RC. Mycoparasitism and plant disease control 161-87 in NM Burge Editor, Fungi in biological control systems. Manchester, United Kingdom: Manchester University Press; 1988. p. 176.

147. Szczesniak O, Hestad K, Hanssen JF, Rudi K. Isovaleric acid in stool correlates with human depression. Nutr Neurosci. 2015 In Press

148. Naseribafrouei A, Hestad K, Avershina E, Sekelja M, Linløkken A, Wilson R, et al. Correlation between the human fecal microbiota and depression. Neurogastroenterol Motil. 2014;26:1155-62.

149. Bested AC, Logan AC, Selhub EM. Intestinal microbiota, probiotics and mental health: from Metchnikoff to modern advances: Part II - contemporary contextual research. Gut Pathog. 2013;5:3.

150. Lorenzo-Zúñiga V, Llop E, Suárez C, Alvarez B, Abreu L, Espadaler J, et al. I.31, a new combination of probiotics, improves irritable bowel syndrome-related quality of life. World J Gastroenterol. 2014;20:8709-16.

151. Yang H, Zhao X, Tang S, Huang H, Zhao X, Ning Z, Fu X, Zhang C. Probiotics reduce psychological stress in patients before laryngeal cancer surgery. Asia Pac J Clin Oncol. 2014 In Press

152. Benton D, Williams C, Brown A. Impact of consuming a milk drink containing a probiotic on mood and cognition. Eur J Clin Nutr. 2007;61:355-61.
153. Rao AV, Bested AC, Beaulne TM, Katzman MA, lorio C, Berardi JM, et al. A randomized, double-blind, placebo-controlled pilot study of a probiotic in emotional symptoms of chronic fatigue syndrome. Gut Pathog. 2009;1:6.

154. Messaoudi M, Lalonde R, Violle N, Javelot H, Desor D, Nejdi A, et al. Assessment of psychotropic-like properties of a probiotic formulation (Lactobacillus helveticus R0052 and Bifidobacterium longum R0175) in rats and human subjects. Br J Nutr. 2011;105:755-64.

155. Messaoudi M, Violle N, Bisson JF, Desor D, Javelot H, Rougeot C. Beneficial psychological effects of a probiotic formulation (Lactobacillus helveticus R0052 and Bifidobacterium longum R0175) in healthy human volunteers. Gut Microbes. 2011;2:256-61.

156. Pärtty A, Kalliomäki M, Wacklin P, Salminen S, Isolauri E. A possible link between early probiotic intervention and the risk of neuropsychiatric disorders later in childhood - a randomized trial. Pediatr Res. 2015 In Press.

157. Galland L. The gut microbiome and the brain. J Med Food. 2014;17:1261-72.

158. Slyepchenko A, Carvalho AF, Cha DS, Kasper S, McIntyre RS. Gut emotions mechanisms of action of probiotics as novel therapeutic targets for depression and anxiety disorders. CNS Neurol Disord Drug Targets. 2014;13:1770-86.

159. Bruce-Keller A, Salbaum JM, Luo M, Taylor CM, Welsh DA, Berthoud HR. Obese-type gut microbiota induce neurobehavioral changes in the absence of obesity. Biol Psychiatry. 2014 In Press

160. Selhub EM, Logan AC, Bested AC. Fermented foods, microbiota, and mental health: ancient practice meets nutritional psychiatry. J Physiol Anthropol. 2014;33:2.

161. Strachan DP. Hay fever, hygiene, and household size. BMJ. 1989;299:1259-60.

162. Wold AE. The hygiene hypothesis revised: is the rising frequency of allergy due to changes in the intestinal flora? Allergy. 1998;53(46 Suppl):20-5.

163. Logan AC, Venket Rao A, Irani D. Chronic fatigue syndrome: lactic acid bacteria may be of therapeutic value. Med Hypotheses. 2003;60:915-23.

164. Logan AC, Katzman MA, Balanzá-Martínez V. Natural environments, ancestral diets, and microbial ecology: is there a modern "paleo-deficit disorder"? Part II J Physiol Anthropol. 2015;34:9.

165. Hesselmar B, Hicke-Roberts A, Wennergren G. Allergy in children in hand versus machine dishwashing. Pediatrics. 2015 In Press

166. Seedorf H, Griffin NW, Ridaura VK, Reyes A, Cheng J, Rey FE, et al. Bacteria from diverse habitats colonize and compete in the mouse gut. Cell. 2014;159:253-66.

167. Wu GD, Compher C, Chen EZ, Smith SA, Shah RD, Bittinger K, Chehoud C, Albenberg LG, Nessel L, Gilroy E, Star J, Weljie AM, Flint HJ, Metz DC, Bennett MJ, Li H, Bushman FD, Lewis JD. Comparative metabolomics in vegans and omnivores reveal constraints on diet-dependent gut microbiota metabolite production. Gut. 2014 In Press

168. Escobar JS, Klotz B, Valdes BE, Agudelo GM. The gut microbiota of Colombians differs from that of Americans. Europeans and Asians BMC Microbiol. 2014;14:311.

169. Ruokolainen $L$, von Hertzen $L$, Fyhrquist N, Laatikainen $T$, Lehtomäki J, Auvinen $P$, et al. Green areas around homes reduce atopic sensitization in children. Allergy. 2015;70:195-202.

170. Hanski I, von Hertzen L, Fyhrquist N, Koskinen K, Torppa K, Laatikainen T, et al. Environmental biodiversity, human microbiota, and allergy are interrelated. Proc Natl Acad Sci U S A. 2012;109:8334-9.

171. Fuller RA, Irvine KN, Devine-Wright P, Warren PH, Gaston KJ. Psychological benefits of greenspace increase with biodiversity. BiolLett. 2007:3:390-4.

172. Luck GW, Davidson P, Boxall D, Smallbone L. Relations between urban bird and plant communities and human well-being and connection to nature. Conservation Biol. 2011;25:816-26.

173. Schwartz A, Turbe A, Simon L, Julliard R. Enhancing urban biodiversity and its influence on city-dwellers: an experiment. Biol Conservation. 2014;171:82-90

174. Muratet A, Pellegrini P, Dufour AB, Arrif T, Chiron F. Perception and knowledge of plant diversity among urban park users. Landscape Urban Plan. 2015;37:95-106

175. Mena C, Fuentes E, Ormazábal Y, Palomo-Vélez G, Palomo I. Role of access to parks and markets with anthropometric measurements, biological markers, and a healthy lifestyle. Int J Environ Health Res. 2014 In Press

176. Hsieh S, Klassen AC, Curriero FC, Caulfield LE, Cheskin LJ, Davis JN, et al. Fast-food restaurants, park access, and insulin resistance among Hispanic youth. Am J Prev Med. 2014;46:378-87.

177. Carroll-Scott A, Gilstad-Hayden K, Rosenthal L, Peters SM, McCaslin C, Joyce $\mathrm{R}$, et al. Disentangling neighborhood contextual associations with child body mass index, diet, and physical activity: the role of built, socioeconomic, and social environments. Soc Sci Med. 2013;95:106-14. 
178. Meyer KA, Boone-Heinonen J, Duffey KJ, Rodriguez DA, Kiefe Cl, Lewis CE, et al. Combined measure of neighborhood food and physical activity environments and weight-related outcomes: The CARDIA study. Health Place. 2015;33C:9-18.

179. Garipe LY, Gónzalez V, Biasizzo A, Soriano JL, Perman G, Giunta D. Food environment and space accessibility evaluation to perform physical activity in 3 socially contrasting neighbourhoods of Buenos Aires city. Rev Fac Cien Med Univ Nac Cordoba. 2014;71:88-96.

180. Haahtela T, Laatikainen T, Alenius H, Auvinen P, Fyhrquist N, Hanski I, von Hertzen L, Jousilahti P, Kosunen TU, Markelova O, Mäkelä MJ, Pantelejev V, Uhanov M, Zilber E, Vartiainen E. Hunt for the origin of allergy - comparing the Finnish and Russian Karelia. Clin Exp Allergy In Press; Schnorr SL. The diverse microbiome of the hunter-gatherer. Nature. 2015 Feb 26;518(7540):S14-5

181. Hidaka BH. Depression as a disease of modernity: explanations for increasing prevalence. J Affect Disord. 2012;140:205-14.

182. Tandon PS, Zhou C, Sallis JF, Cain KL, Frank LD, Saelens BE. Home environment relationships with children's physical activity, sedentary time, and screen time by socioeconomic status. Int J Behav Nutr Phys Act. 2012;9:88.

183. Jin Y, Jones-Smith JC. Associations between family income and children's physical fitness and obesity in California, 2010-2012. Prev Chronic Dis. 2015;12:E17.

184. Hillier A, Tappe K, Cannuscio C, Karpyn A, Glanz K. In an urban neighborhood, who is physically active and where? Women Health. 2014;54:194-211.

185. Adlakha D, Budd EL, Gernes R, Sequeira S, Hipp JA. Use of emerging technologies to assess differences in outdoor physical activity in St. Louis, Missouri. Front. Public Health. 2014;2:41.

186. Wijtzes Al, Jansen W, Bouthoorn SH, Pot N, Hofman A, Jaddoe WW, et al. Social inequalities in young children's sports participation and outdoor play. Int J Behav Nutr Phys Act. 2014;11:155.

187. Carson V, Janssen I. Neighborhood disorder and screen time among 10-16 year old Canadian youth: a cross-sectional study. Int J Behav Nutr Phys Act. 2012;9:66.

188. Bagley EJ, Kelly RJ, Buckhalt JA, El-Sheikh M. What keeps low-SES children from sleeping well: the role of presleep worries and sleep environment. Sleep Med. 2015;16:496-502.

189. Fang SC, Subramanian SV, Piccolo R, Yang M, Yaggi HK, Bliwise DL, et al. Geographic variations in sleep duration: a multilevel analysis from the Boston Area Community Health (BACH) Survey. J Epidemiol Community Health. 2015:69(1):63-9.

190. Jackson CL, Redline S, Emmons KM. Sleep as a potential fundamental contributor to disparities in cardiovascular health. Annu Rev Public Health. 2015;36:417-40.

191. Cohen DA, Sturm R, Scott M, Farley TA, Bluthenthal R. Not enough fruit and vegetables or too many cookies, candies, salty snacks, and soft drinks? Public Health Rep. 2010;125:88-95.

192. Tate NH, Dillaway HE, Yarandi HN, Jones LM, Wilson FL. An examination of eating behaviors, physical activity, and obesity in African American adolescents: gender, socioeconomic status, and residential status differences. J Pediatr Health Care. 2015 In Press

193. Ji C, Cappuccio FP. Socioeconomic inequality in salt intake in Britain 10 years after a national salt reduction programme. BMJ Open. 2014;4:e005683.

194. Araújo J, Teixeira J, Gaio AR, Lopes C, Ramos E. Dietary patterns among 13-y-old Portuguese adolescents. Nutrition. 2015;31:148-54.

195. Larson N, Story M. Barriers to equity in nutritional health for U.S. children and adolescents: a review of the literature. Curr Nutr Rep. 2015;4:102-10.

196. Barton KL, Wrieden WL, Sherriff A, Armstrong J, Anderson AS. Trends in socio-economic inequalities in the Scottish diet: 2001-2009. Public Health Nutr. 2015;16:1-12.

197. Caetano R, Vaeth PA, Chartier KG, Mills BA. Epidemiology of drinking, alcohol use disorders, and related problems in US ethnic minority groups. Handb Clin Neurol. 2014;125:629-48.

198. Fone DL, Farewell DM, White J, Lyons RA, Dunstan FD. Socioeconomic patterning of excess alcohol consumption and binge drinking: a cross-sectional study of multilevel associations with neighbourhood deprivation. BMJ Open. 2013;3:e002337.

199. Cano MÁ, Wetter DW. Socioeconomic status and smoking cessation: neighborhood context as an underlying mechanism. Tex Heart Inst J. 2014;41:309-10.
200. Shiue I. Correlations of indoor second-hand smoking, household smoking rules, regional deprivation and children mental health: Scottish Health Survey, 2013. Environ Sci Pollut Res Int. 2015 In Press

201. Shin YH, Shin HJ, Lee YJ. Vitamin D status and childhood health. Korean J Pediatr. 2013;56:417-23.

202. Knox S, Welsh P, Bezlyak V, McConnachie A, Boulton E, Deans KA, et al. 25-Hydroxyvitamin $D$ is lower in deprived groups, but is not associated with carotid intima media thickness or plaques: results from pSoBid. Atherosclerosis. 2012;223:437-41.

203. Li PL, Tian YJ, Wang YH, Zhang CZ, Gao J, Li YH, Li SJ. The prevalence of vitamin D deficiency among schoolchildren: a cohort study from Xinxiang, China. J Pediatr Endocrinol Metab. 2015 In Press

204. Cohen BE, Garg SK, Ali S, Harris WS, Whooley MA. Red blood cell docosahexaenoic acid and eicosapentaenoic acid concentrations are positively associated with socioeconomic status in patients with established coronary artery disease: data from the Heart and Soul Study. J Nutr. 2008;138:1135-40.

205. Suares NC, Ford AC. Prevalence of, and risk factors for, chronic idiopathic constipation in the community: systematic review and meta-analysis. Am J Gastroenterol. 2011;106(9):1582-91.

206. Foster D, Spruill L, Walter KR, Nogueira LM, Fedarovich H, Turner RY, et al. AGE metabolites: a biomarker linked to cancer disparity? Cancer Epidemiol Biomarkers Prev. 2014;23(10):2186-91.

207. Marques S, Lima ML. Living in grey areas: industrial activity and psychological health. J Environ Psychol. 2011;31:314-22.

208. Stewart IT, Bacon CM, Burke WD. The uneven distribution of environmental burdens and benefits in Silicon Valley's backyard. Appl Geogr. 2014;55:266-77.

209. Gaither CJ. Smokestacks, parkland, and community composition: examining the environmental burdens and benefits of Hall County, Georgia, USA. Environ Behav. 2014 In Press

210. Romley JA, Cohen D, Ringel J, Sturm R. Alcohol and environmental justice: the density of liquor stores and bars in urban neighborhoods in the United States. J Stud Alcohol Drugs. 2007:68:48-55.

211. Hricko A, Rowland G, Eckel S, Logan A, Taher M, Wilson J. Global trade, local impacts: lessons from California on health impacts and environmental justice concerns for residents living near freight rail yards. Int J Environ Res Public Health. 2014;11:1914-41.

212. Drewnowski A, Aggarwal A, Rehm CD, Cohen-Cline H, Hurvitz PM, Moudon AV. Environments perceived as obesogenic have lower residential property values. Am J Prev Med. 2014;47:260-74.

213. Block JP, Scribner RA, DeSalvo KB. Fast food, race/ethnicity, and income: a geographic analysis. Am J Prev Med. 2004;27(3):211-7.

214. Marashi-Pour S, Cretikos M, Lyons C, Rose N, Jalaludin B, Smith J. The association between the density of retail tobacco outlets, individual smoking status, neighbourhood socioeconomic status and school locations in New South Wales. Australia Spat Spatiotemporal Epidemiol. 2015;12:1-7.

215. Lee RE, Heinrich KM, Reese-Smith JY, Regan GR, Adamus-Leach HJ. Obesogenic and youth oriented restaurant marketing in public housing neighborhoods. Am J Health Behav. 2014;38:218-24.

216. Fleming-Milici F, Harris $J$, Sarda V, Schwartz MB. Amount of Hispanic youth exposure to food and beverage advertising on Spanish- and English-language television. JAMA Pediatr. 2013;167:723-30.

217. Kunkel D, Mastro D, Ortiz M, McKinley C. Food marketing to children on U.S. Spanish-language television. J Health Commun. 2013;18:1084-96.

218. Lowery BC, Sloane DC. The prevalence of harmful content on outdoor advertising in Los Angeles: land use, community characteristics, and the spatial inequality of a public health nuisance. Am J Public Health. 2014;104:658-64.

219. Lesser LI, Zimmerman FJ, Cohen DA. Outdoor advertising, obesity, and soda consumption: a cross-sectional study. BMC Public Health. 2013;13:20

220. Yancey AK, Cole BL, Brown R, Williams JD, Hillier A, Kline RS, et al. A cross-sectional prevalence study of ethnically targeted and general audience outdoor obesity-related advertising. Milbank Q. 2009;87:155-84.

221. Hillier A, Chilton M, Zhao QW, Szymkowiak D, Coffman R, Mallya G. Concentration of tobacco advertisements at SNAP and WIC stores, Philadelphia, Pennsylvania, 2012. Prev Chronic Dis. 2015 In Press

222. Powell LM, Wada R, Kumanyika SK. Racial/ethnic and income disparities in child and adolescent exposure to food and beverage television ads across the U.S. media markets. Health Place. 2014;29:124-31.

223. Pasch KE, Komro KA, Perry CL, Hearst MO, Farbakhsh K. Does outdoor alcohol advertising around elementary schools vary by the ethnicity of students in the school? Ethn Health. 2009;14:225-36. 
224. Cantrell J, Kreslake JM, Ganz O, Pearson JL, Vallone D, Anesetti-Rothermel A, et al. Marketing little cigars and cigarillos: advertising, price, and associations with neighborhood demographics. Am J Public Health. 2013;103:1902-9.

225. Pasch KE, Poulos NS. Outdoor food and beverage advertising: a saturated environment. Adv Comm Res Reduce Childhood Obes. 2013;1:303-15.

226. Settle PJ, Cameron AJ, Thornton LE. Socioeconomic differences in outdoor food advertising at public transit stops across Melbourne suburbs. Aust N Z J Public Health. 2014;38:414-8.

227. Arredondo E, Castaneda D, Elder JP, Slymen D, Dozier D. Brand name logo recognition of fast food and healthy food among children. J Community Health. 2009;34:73-8

228. Laxer RE, Janssen I. The proportion of excessive fast-food consumption attributable to the neighborhood food environment among youth living within $1 \mathrm{~km}$ of their school. Appl Physiol Nutr Metab. 2014;39:480-6.

229. Goryakin Y, Rocco L, Suhrcke M, Roberts B, McKee M. Fruit and vegetable consumption in the former Soviet Union: the role of individual- and community-level factors. Public Health Nutr. 2015;17:1-11.

230. Zimmerman FJ, Shimoga SV. The effects of food advertising and cognitive load on food choices. BMC Public Health. 2014;14:342.

231. Baker EA, Schootman M, Barnidge $E$, Kelly $C$. The role of race and poverty in access to foods that enable individuals to adhere to dietary guidelines. Prev Chronic Dis. 2006:3:A76.

232. Cannuscio CC, Tappe K, Hillier A, Buttenheim A, Karpyn A, Glanz K. Urban food environments and residents' shopping behaviors. Am J Prev Med. 2013:45:606-14.

233. Hill JL, Olive NC, Waters CN, Estabrooks PA, You W, Zoellner JM. Lack of healthy food options on children's menus of restaurants in the health-disparate Dan River Region of Virginia and North Carolina, 2013. Prev Chronic Dis. 2015;12:E40.

234. Cameron AJ, Thornton LE, McNaughton SA, Crawford D. Variation in supermarket exposure to energy-dense snack foods by socio-economic position. Public Health Nutr. 2013;16:1178-85.

235. Farley TA, Rice J, Bodor JN, Cohen DA, Bluthenthal RN, Rose D. Measuring the food environment: shelf space of fruits, vegetables, and snack foods in stores. J Urban Health. 2009:86:672-82.

236. Rose D, Hutchinson PL, Bodor JN, Swalm CM, Farley TA, Cohen DA, et al. Neighborhood food environments and body mass index: the importance of in-store contents. Am J Prev Med. 2009;37:214-9.

237. Franco M, Diez Roux AV, Glass TA, Caballero B, Brancati FL. Neighborhood characteristics and availability of healthy foods in Baltimore. Am J Prev Med. 2008;35:561-7.

238. Andreyeva T, Blumenthal DM, Schwartz MB, Long MW, Brownell KD. Availability and prices of foods across stores and neighborhoods: the case of New Haven. Connecticut Health Aff. 2008;27:1381-8.

239. Adjoian T, Dannefer R, Sacks R, Van Wye G. Comparing sugary drinks in the food retail environment in six NYC neighborhoods. J Community Health. 2014;39:327-35.

240. Grigsby-Toussaint DS, Moise IK, Geiger SD. Observations of marketing on food packaging targeted to youth in retail food stores. Obesity. 2011;19:1898-900.

241. Jokela M, Singh-Manoux A, Shipley MJ, Ferrie JE, Gimeno D, Akbaraly TN, et al. Natural course of recurrent psychological distress in adulthood. J Affect Disord. 2011;130:454-61.

242. Robinson RL, Stephenson JJ, Dennehy EB, Grabner M, Faries D, Palli SR, Swindle RW. The importance of unresolved fatigue in depression: costs and comorbidities. Psychosomatics. 2014 In Press

243. Morris MJ, Beilharz JE, Maniam J, Reichelt AC, Westbrook RF. Why is obesity such a problem in the 21 st century? The intersection of palatable food, cues and reward pathways, stress, and cognition. Neurosci Biobehav Rev. 2014 In Press

244. Tomiyama AJ, Dallman MF, Epel ES. Comfort food is comforting to those most stressed: evidence of the chronic stress response network in high stress women. Psychoneuroendocrinology. 2011;36:1513-9.

245. Zenk SN, Horoi I, McDonald A, Corte C, Riley B, Odoms-Young AM Ecological momentary assessment of environmental and personal factors and snack food intake in African American women. Appetite. 2014;83:333-41.

246. Smith TC, LeardMann CA, Smith B, Jacobson IG, Miller SC, Wells TS, et al Longitudinal assessment of mental disorders, smoking, and hazardous drinking among a population-based cohort of US service members. J Addict Med. 2014;8:271-81.

247. Penetar DM, Lindsey KP, Peters EN, Juliano TM, Lukas SE. Decreasing nicotine content reduces subjective and physiological effects of smoking Tob Use Insights. 2012;5:1-9.
248. Childs E, de Wit H. Effects of acute psychosocial stress on cigarette craving and smoking. Nicotine Tob Res. 2010;12:449-53.

249. Devine CM, Jastran M, Jabs J, Wethington E, Farell TJ, Bisogni CA. "A lot of sacrifices:" work-family spillover and the food choice coping strategies of low-wage employed parents. Soc Sci Med. 2006;63:2591-603.

250. Nagler EM, Viswanath K, Ebbeling CB, Stoddard AM, Sorensen G. Correlates of fruit and vegetable consumption among construction laborers and motor freight workers. Cancer Causes Control. 2013;24:637-47.

251. Leung CW, Epel ES, Ritchie LD, Crawford PB, Laraia BA. Food insecurity is inversely associated with diet quality of lower-income adults. J Acad Nutr Diet. 2014;114:1943-53.e2.

252. Hanson KL, Connor LM. Food insecurity and dietary quality in US adults and children: a systematic review. Am J Clin Nutr. 2014;100:684-92.

253. Armeli S, O'Hara RE, Ehrenberg E, Sullivan TP, Tennen H. Episode-specific drinking-to-cope motivation, daily mood, and fatigue-related symptoms among college students. J Stud Alcohol Drugs. 2014;75:766-74.

254. Chambers EC, Pichardo MS, Rosenbaum E. Sleep and the housing and neighborhood environment of urban Latino adults living in low-income housing: the AHOME study. Behav Sleep Med. 2014;11:1-16.

255. Ruiz-Castell M, Muckle G, Dewailly É, Jacobson JL, Jacobson SW, Ayotte P, et al. Household crowding and food insecurity among Inuit families with school-aged children in the Canadian Arctic. Am J Public Health. 2015;105:e122-32

256. Fecht D, Fischer P, Fortunato L, Hoek G, de Hoogh K, Marra M, et al. Associations between air pollution and socioeconomic characteristics, ethnicity and age profile of neighbourhoods in England and the Netherlands. Environ Pollut. 2015;198:201-10.

257. Clark LP, Millet DB, Marshall JD. National patterns in environmental injustice and inequality: outdoor NO2 air pollution in the United States. PLoS One. 2014;9:e94431.

258. Su JG, Jerrett M, de Nazelle A, Wolch J. Does exposure to air pollution in urban parks have socioeconomic, racial or ethnic gradients? Environ Res. 2011;111(3):319-28.

259. Morrison S, Fordyce FM, Scott EM. An initial assessment of spatial relationships between respiratory cases, soil metal content, air quality and deprivation indicators in Glasgow, Scotland, UK: relevance to the environmental justice agenda. Environ Geochem Health. 2014;36:319-32.

260. Filippelli GM, Laidlaw MA. The elephant in the playground: confronting lead-contaminated soils as an important source of lead burdens to urban populations. Perspect Biol Med. 2010;53:31-45.

261. Gronlund CJ. Racial and socioeconomic disparities in heat-related health effects and their mechanisms: a review. Curr Epidemiol Rep. 2014;1:165-73.

262. Eriksson C, Hilding A, Pyko A, Bluhm G, Pershagen G, Östenson CG. Long-term aircraft noise exposure and body mass index, waist circumference, and type 2 diabetes: a prospective study. Environ Health Perspect. 2014;122:687-94.

263. Méline J, Van Hulst A, Thomas F, Karusisi N, Chaix B. Transportation noise and annoyance related to road traffic in the French RECORD study. Int J Health Geogr. 2013;12:44.

264. Laussmann D, Haftenberger M, Lampert T, Scheidt-Nave C. Social inequities regarding annoyance to noise and road traffic intensity: results of the German Health Interview and Examination Survey for Adults (DEGS1). Bundesgesundheitsblatt Gesundheitsforschung Gesundheitsschutz. 2013;56:822-31.

265. Shiue I. Neighborhood epidemiological monitoring and adult mental health: European Quality of Life Survey, 2007-2012. Environ Sci Pollut Res Int. 2014 In Press

266. Bocquier A, Cortaredona S, Boutin C, Davis A, Bigot A, Sciortino V, et al Is exposure to night-time traffic noise a risk factor for purchase of anxiolytichypnotic medication? A cohort study. Eur J Public Health. 2014;24:298-303.

267. Covvey JR, Johnson BF, Elliott V, Malcolm W, Mullen AB. An association between socioeconomic deprivation and primary care antibiotic prescribing in Scotland. J Antimicrob Chemother. 2014;69:835-41.

268. Hicks LA, Bartoces MG, Roberts RM, Suda KJ, Hunkler RJ, Taylor TH Jr, Schrag SJ. US outpatient antibiotic prescribing variation according to geography, patient population, and provider specialty in 2011. Clin Infect Dis. 2015 In Press

269. Davis JE, Freel N, Findley A, Tomlin K, Howard KM, Seran CC, et al. A molecular survey of S. mutans and $\mathrm{P}$. gingivalis oral microbial burden in human saliva using relative endpoint polymerase chain reaction (RE-PCR) within the population of a Nevada dental school revealed disparities among minorities. BMC Oral Health. 2012;12:34. 
270. Kyba CC, Tong KP, Bennie J, Birriel I, Birriel JJ, Cool A, et al. Worldwide variations in artificial skyglow. Sci Rep. 2015;5:8409.

271. Gaston KJ, Duffy JP, Bennie J. Quantifying the erosion of natural darkness in the global protected area system. Conserv Biol. 2015 In Press

272. Hurley S, Nelson DO, Garcia E, Gunier R, Hertz A, Reynolds P. A cross-sectional analysis of light at night, neighborhood sociodemographics and urinary 6-sulfatoxymelatonin concentrations: implications for the conduct of health studies. Int J Health Geogr. 2013;12:39.

273. Knowles SR, Nelson EA, Palombo EA. Investigating the role of perceived stress on bacterial flora activity and salivary cortisol secretion: a possible mechanism underlying susceptibility to illness. Biol Psychol. 2008;77:132-7.

274. Sundin J, Rangel I, Fuentes S, Heikamp-de Jong I, Hultgren-Hörnquist E, de Vos WM, et al. Altered faecal and mucosal microbial composition in post-infectious irritable bowel syndrome patients correlates with mucosal lymphocyte phenotypes and psychological distress. Aliment Pharmacol Ther. 2015;41:342-51.

275. Zijlmans MA, Korpela K, Riksen-Walraven JM, de Vos WM, de Weerth C. Maternal prenatal stress is associated with the infant intestinal microbiota. Psychoneuroendocrinology. 2015;53:233-45.

276. Lyte M. The effect of stress on microbial growth. Anim Health Res Rev. 2014;15(2):172-4.

277. Condette CJ, Bach V, Mayeur C, Gay-Quéheillard J, Khorsi-Cauet H. Chlorpyrifos Exposure during perinatal period impacts intestinal microbiota associated with delay of maturation of digestive tract in rats. J Pediatr Gastroenterol Nutr. 2015 In Press

278. Joly C, Gay-Quéheillard J, Léké A, Chardon K, Delanaud S, Bach V, et al. Impact of chronic exposure to low doses of chlorpyrifos on the intestinal microbiota in the Simulator of the Human Intestinal Microbial Ecosystem (SHIME) and in the rat. Environ Sci Pollut Res Int. 2013;20:2726-34.

279. Salim SY, Kaplan GG, Madsen K. Air pollution effects on the gut microbiota: a link between exposure and inflammatory disease. Gut Microbes. 2014:5:215-9.

280. Choi JJ, Eum SY, Rampersaud E, Daunert S, Abreu MT, Toborek M. Exercise attenuates PCB-induced changes in the mouse gut microbiome. Environ Health Perspect. 2013;121:725-30.

281. Kohl KD, Cary TL, Karasov WH, Dearing MD. Larval exposure to polychlorinated biphenyl 126 (PCB-126) causes persistent alteration of the amphibian gut microbiota. Environ Toxicol Chem. 2015 In Press

282. Breton J, Massart S, Vandamme P, De Brandt E, Pot B, Foligné B. Ecotoxicology inside the gut: impact of heavy metals on the mouse microbiome. BMC Pharmacol Toxicol. 2013;14:62.

283. Tannock GW. The lactic microflora of pigs, mice and rats. Lactic Acid Bacter. 1992:1:21-48.

284. Timofeyev I, Loseva E, Alekseeva T, Perminova N. Stability to sound stress and changeability in intestinal microflora. Eur Psychiatry. 2002;17:200S.

285. Suzuki K, Harasawa R, Yoshitake Y, Mitsuoka T. Effects of crowding and heat stress on intestinal flora, body weight gain, and feed efficiency of growing rats and chicks. Nihon Juigaku Zasshi. 1983;45(3):331-8.

286. Graf D, Di Cagno R, Fåk F, Flint HJ, Nyman M, Saarela M, et al. Contribution of diet to the composition of the human gut microbiota. Microb Ecol Health Dis. 2015:26:26164.

287. Yang Y, Zheng L, Wang L, Wang S, Wang Y, Han Z. Effects of high fructose and salt feeding on systematic metabonome probed via $1 \mathrm{H} \mathrm{NMR}$ spectroscopy. Magn Reson Chem. 2015 In Press

288. Seiquer I, Rubio LA, Peinado MJ, Delgado-Andrade C, Navarro MP. Maillard reaction products modulate gut microbiota composition in adolescents. Mol Nutr Food Res. 2014;58:1552-60.

289. Chassaing B, Koren O, Goodrich JK, Poole AC, Srinivasan S, Ley RE, Gerwitz AT. Dietary emulsifiers impact the mouse gut microbiota promoting colitis and metabolic syndrome. Nature. 2015 In Press

290. Qiao Y, Sun J, Xia S, Tang X, Shi Y, Le G. Effects of resveratrol on gut microbiota and fat storage in a mouse model with high-fat-induced obesity. Food Funct. 2014;5:1241-9.

291. Greiner AK, Papineni RV, Umar S. Chemoprevention in gastrointestinal physiology and disease. Natural products and microbiome. Am J Physiol Gastrointest Liver Physiol. 2014;307:G1-15.

292. Winther G, Pyndt Jørgensen BM, Elfving B, Nielsen DS, Kihl P, Lund S, et al. Dietary magnesium deficiency alters gut microbiota and leads to depressive-like behaviour. Acta Neuropsychiatr. 2015;18:1-9.

293. Cao ZJ, Yu JC, Kang WM, Ma ZQ, Ye X, Tian SB. Effect of $n-3$ polyunsaturated fatty acids on gut microbiota and endotoxin levels in portal vein of rats fed with high-fat diet. Zhongguo Yi Xue Ke Xue Yuan Xue Bao. 2014;36:496-500.

294. Modi SR, Collins JJ, Relman DA. Antibiotics and the gut microbiota. J Clin Invest. 2014;124:4212-8.

295. Leclercq S, Matamoros S, Cani PD, Neyrinck AM, Jamar F, Stärkel P, et al. Intestinal permeability, gut-bacterial dysbiosis, and behavioral markers of alcohol-dependence severity. Proc Natl Acad Sci U S A. 2014;111:E4485-93.

296. Campos Canesso M, Lacerda Queiroz N, Marcantonio C, Lauar J, Almeida D, Gamba C, et al. Comparing the effects of acute alcohol consumption in germ-free and conventional mice: the role of the gut microbiota. BMC Microbiol. 2014;14:240

297. Arimatsu K, Yamada H, Miyazawa H, Minagawa T, Nakajima M, Ryder MI, et al. Oral pathobiont induces systemic inflammation and metabolic changes associated with alteration of gut microbiota. Sci Rep. 2014;4:4828.

298. Biedermann L, Zeitz J, Mwinyi J, Sutter-Minder E, Rehman A, Ott SJ, et al. Smoking cessation induces profound changes in the composition of the intestinal microbiota in humans. PLoS One. 2013;8:e59260.

299. Wang H, Zhao JX, Hu N, Ren J, Du M, Zhu MJ. Side-stream smoking reduces intestinal inflammation and increases expression of tight junction proteins. World J Gastroenterol. 2012;18:2180-7.

300. Matsumoto M, Inoue R, Tsukahara T, Ushida K, Chiji H, Matsubara N, et al. Voluntary running exercise alters microbiota composition and increases n-butyrate concentration in the rat cecum. Biosci Biotechnol Biochem. 2008;72:572-6.

301. Thaiss CA, Zeevi D, Levy M, Zilberman-Schapira G, Suez J, Tengeler AC, et al. Transkingdom control of microbiota diurnal oscillations promotes metabolic homeostasis. Cell. 2014;159:514-29.

302. Ono S, Komada Y, Kamiya T, Shirakawa S. A pilot study of the relationship between bowel habits and sleep health by actigraphy measurement and fecal flora analysis. J Physiol Anthropol. 2008;27(3):145-51.

303. Jahani R, Fielding KA, Chen J, Villa CR, Castelli LM, Ward WE, et al. Low vitamin D status throughout life results in an inflammatory prone status but does not alter bone mineral or strength in healthy 3-month-old CD-1 male mice. Mol Nutr Food Res. 2014;58:1491-501.

304. Assa A, Vong L, Pinnell LJ, Avitzur N, Johnson-Henry KC, Sherman PM. Vitamin D deficiency promotes epithelial barrier dysfunction and intestinal inflammation. J Infect Dis. 2014;210(8):1296-305.

305. Sylvetsky AC, Welsh JA, Brown RJ, Vos MB. Low-calorie sweetener consumption is increasing in the United States. Am J Clin Nutr. 2012;96:640-6.

306. Palmnäs MS, Cowan TE, Bomhof MR, Su J, Reimer RA, Vogel HJ, et al. Low-dose aspartame consumption differentially affects gut microbiota-host metabolic interactions in the diet-induced obese rat. PLoS One. 2014;9:e109841.

307. Suez J, Korem T, Zeevi D, Zilberman-Schapira G, Thaiss CA, Maza O, et al. Artificial sweeteners induce glucose intolerance by altering the gut microbiota. Nature. 2014;514:181-6.

308. Abou-Donia MB, El-Masry EM, Abdel-Rahman AA, McLendon RE, Schiffman SS. Splenda alters gut microflora and increases intestinal p-glycoprotein and cytochrome p-450 in male rats. J Toxicol Environ Health A. 2008;71:1415-29.

309. Weil TP. Insufficient dollars and qualified personnel to meet United States mental health needs. J Nerv Ment Dis. 2015;203(4):233-40.

310. Goodman G, Gershwin ME, Bercovich D. Mars can wait: facing the challenges of our civilization. Isr Med Assoc J. 2014;16:744-7.

311. Smith K. Trillion-dollar brain drain. Nature. 2011;478:15.

312. Rampell K. The Half-Trillion-Dollar Depression. New York Times Magazine July. 2013;7:MM14.

313. Bouchery EE, Harwood HJ, Sacks JJ, Simon CJ, Brewer RD. Economic costs of excessive alcohol consumption in the U.S., 2006. Am J Prev Med. 2011;41:516-24.

314. Hansen RN, Oster G, Edelsberg J, Woody GE, Sullivan SD. Economic costs of nonmedical use of prescription opioids. Clin J Pain. 2011;27:194-202.

315. Metz GA, Ng JW, Kovalchuk I, Olson DM. Ancestral experience as a game changer in stress vulnerability and disease outcomes. Bioessays. 2015 In Press

316. Logan AC, Katzman M. Major depressive disorder: probiotics may be an adjuvant therapy. Med Hypotheses. 2005;64:533-8.

317. Reardon S. Gut-brain link grabs neuroscientists. Nature. 2014;515(7526):175-7.

318. Young KA. Of poops and parasites: unethical FDA overregulation. Food Drug Law J. 2014;69:555-74.

319. Garber K. Drugging the microbiome. Nat Biotechnol. 2015;33(3):228-31.

320. Dinan TG, Stanton C, Cryan JF. Psychobiotics: a novel class of psychotropic. Biol Psychiatry. 2013;74(10):720-6.

321. Hirose Y, Yamamoto Y, Yoshikai Y, Murosaki S. Oral intake of heat-killed Lactobacillus plantarum L-137 decreases the incidence of upper respiratory 
tract infection in healthy subjects with high levels of psychological stress. J Nutr Sci. 2013;2, e39.

322. Sashihara T, Nagata M, Mori T, Ikegami S, Gotoh M, Okubo K, et al. Effects of Lactobacillus gasseri OLL2809 and a-lactalbumin on university-student athletes: a randomized, double-blind, placebo-controlled clinical trial. Appl Physiol Nutr Metab. 2013;38(12):1228-35.

323. Fyhrquist N, Ruokolainen L, Suomalainen A, Lehtimäki S, Veckman V, Vendelin J, et al. Acinetobacter species in the skin microbiota protect against allergic sensitization and inflammation. J Allergy Clin Immunol. 2014;134(6):1301-9. e11.

324. Castro DC, Samuels M, Harman AE. Growing healthy kids: a community garden-based obesity prevention program. Am J Prev Med. 2013:44(3 Suppl 3):S193-9.

325. Mojtabai R, Jorm AF. Trends in psychological distress, depressive episodes and mental health treatment-seeking in the United States: 2001-2012. J Affect Disord. 2015;174:556-61.

326. Keyes KM, Nicholson R, Kinley J, Raposo S, Stein MB, Goldner EM, et al. Age, period, and cohort effects in psychological distress in the United States and Canada. Am J Epidemiol. 2014;179(10):1216-27.

327. Kirsch I. The emperor's new drugs: medication and placebo in the treatment of depression. Handb Exp Pharmacol. 2014;225:291-303.

328. Khan A, Faucett J, Lichtenberg P, Kirsch I, Brown WA. A systematic review of comparative efficacy of treatments and controls for depression. PLoS One. 2012; 7 , e41778.

329. Cuijpers P, Smit F, Bohlmeijer E, Hollon SD, Andersson G. Efficacy of cognitive-behavioural therapy and other psychological treatments for adult depression: meta-analytic study of publication bias. Br J Psychiatry. 2010;196:173-8

330. Cuijpers P, Berking M, Andersson G, Quigley L, Kleiboer A, Dobson KS. A meta-analysis of cognitive-behavioural therapy for adult depression, alone and in comparison with other treatments. Can J Psychiatry. 2013;58:376-85.

331. Furukawa TA, Noma H, Caldwell DM, Honyashiki M, Shinohara K, Imai H, Chen P, Hunot V, Churchill R. Waiting list may be a nocebo condition in psychotherapy trials: a contribution from network meta-analysis. Acta Psychiatr Scand. 2014 In Press

332. Cuijpers P, Turner EH, Mohr DC, Hofmann SG, Andersson G, Berking M, et al. Comparison of psychotherapies for adult depression to pill placebo control groups: a meta-analysis. Psychol Med. 2014;44:685-95.

333. Flint J, Cuijpers P, Horder J, Koole SL, Munafò MR. Is there an excess of significant findings in published studies of psychotherapy for depression? Psychol Med. 2014 In Press

334. Jacka FN, Reavley NJ. Prevention of mental disorders: evidence, challenges and opportunities. BMC Med. 2014;12:75.

335. Schmidt C. Mental health: thinking from the gut. Nature. 2015;518(7540):S12-5.

336. Belstrøm D, Holmstrup P, Nielsen CH, Kirkby N, Twetman S, Heitmann BL, et al. Bacterial profiles of saliva in relation to diet, lifestyle factors, and socioeconomic status. J Oral Microbiol. 2014;1:6.

337. Anton D, Shelton DL. Problems in Environmental Protection and Human Rights: A Human Right to the Environment (June 26, 2011). ANU College of Law Research Paper No. 11-17. p 1-33. http://papers.ssrn.com/sol3/ papers.cfm?abstract_id=1872937

\section{Submit your next manuscript to BioMed Central and take full advantage of:}

- Convenient online submission

- Thorough peer review

- No space constraints or color figure charges

- Immediate publication on acceptance

- Inclusion in PubMed, CAS, Scopus and Google Scholar

- Research which is freely available for redistribution

Submit your manuscript at www.biomedcentral.com/submit 